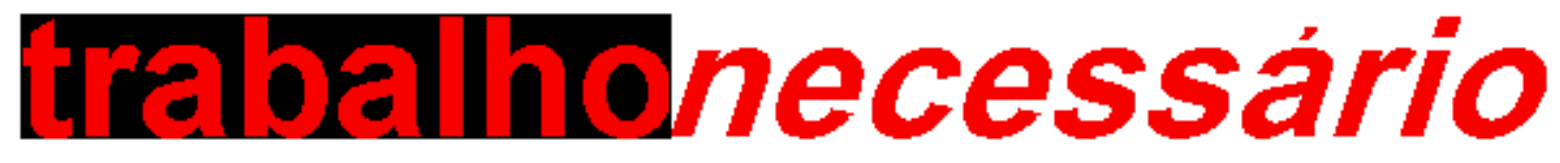

issn: $1808-799 \mathrm{X}$

ano 4 - número 4 - 2006

\title{
SOBRE O DISCURSO DO (DES)EMPREGO NO GOVERNO LULA
}

Cinco Estudos sobre a Relação entre Educação e Emprego no Discurso do Ministro do Trabalho

José Rodrigues (org.)[1]

Jane Barros Almeida

Mônica Ribeiro de Araújo

Ana Cristina Costa dos Santos de Castro

Zuleide Simas da Silveira

Ozias de Jesus Soares

\section{Apresentação}

Passados praticamente quatro anos desde a eleição de Luiz Inácio Lula da Silva à presidência da República, e da famosa Carta ao Povo Brasileiro[1], a qual explicitou categoricamente sua submissão às regras, demandas e necessidades do Capital, muitos segmentos sociais e políticos ainda se encontram, de certa forma, paralisados diante das políticas econômica, social e educacional emanadas de Brasília.

Aliás, pelo que indicam as pesquisas de opinião pública, há grande chance de Lula ser reeleito já no primeiro turno. Nesse sentido, muitos setores deixaram a paralisia e integraram-se de corpo e alma no trabalho de construir a implantação e a continuidade da política neoliberal continuísta do Partido dos Trabalhadores e de seus aliados (ou sócios).

Neste contexto, propusemos aos nossos estudantes de Economia Política da Educação, disciplina do Programa de Pós-Graduação em Educação da Universidade Federal Fluminense, ministrada no segundo semestre letivo de 2005, que elaborassem um breve artigo que analisasse a relação trabalho-educação a partir da entrevista de Luiz Marinho, ministro do Trabalho e Emprego, concedida a Lea Cristina, publicada no caderno Boa Chance de $\mathbf{O}$ Globo, intitulada $\mathbf{O}$ emprego não acabou (anexa a este dossiê).

Ora, cabe lembrar que Luiz Marinho é figura emblemática daquele grupo de trânsfugas de classe denominado de maneira tão primorosa quanto jocosa por Francisco de Oliveira: o ornitorrinco. Daí a dupla relevância da entrevista: o discurso oficial do Governo Lula da 
Silva sobre a relação trabalho-educação, proferido por um ex-presidente da outrora classista e socialista Central Única dos Trabalhadores.

Os estudos que seguem são precisamente alguns dos textos redigidos pelos então estudantes de Economia Política de Educação, todos do campo de Trabalho e Educação, que dada a qualidade, pertinência e relevância, achamos por bem tornar públicos.

O estudo I - A naturalização do desemprego estrutural - de autoria de Jane Barros de Almeida, orientada de Ronaldo Rosas Reis, destaca no discurso do ministro a visão naturalizante (e desistoricizante) dos problemas sociais, em especial o desemprego industrial, historicamente constituído no modo de produção capitalista, em sua versão neoliberal.

O estudo II, de autoria de Mônica Ribeiro de Araújo, mestranda sob minha orientação, é intitulado "O emprego não acabou, os trabalhadores estão desqualificados": os novos atributos pessoais demandados pelo capital, ressalta as novas relações entre 0 público e o privado, firmadas com o intento de "sanar" os problemas referentes à educação, aliás, limitados aos ditames da Conferência Mundial sobre Educação para Todos, cuja meta "viável" é a "Satisfação das Necessidades Básicas de Aprendizagem".

Ana Cristina Costa dos Santos de Castro, autora do estudo III - É possível reproduzir a vida contando apenas com um emprego no mercado formal?: Discutindo estratégias de trabalho e de sobrevivência -, seguindo a linha de pesquisa de sua orientadora Lia Tiriba, coloca a ênfase de seu estudo nas relações entre o discurso ministerial, o desemprego estrutural e as estratégias populares de economia solidária.

Segundo as estatísticas apresentadas pelo MTE, o emprego cresceu, a produção industrial aumentou. Mas em que condições? É esta a pergunta que Zuleide Simas da Silveira, orientanda de Maria Ciavatta, procura responder no estudo IV, intitulado "O emprego não acabou": retórica?

O quinto e último estudo, intitulado Fios do discurso e armadilhas da promessa: provocações de uma entrevista, de autoria de Ozias de Jesus Soares, então orientando de Lia Tiriba, puxa os múltiplos fios do discurso do ministro, revelando as armadilhas postas ao trabalhador pelas promessas de um futuro incerto, e lança uma pergunta ainda sem resposta: "por quanto tempo ficará a classe trabalhadora desmobilizada e fragilizada diante de vazios discursos e promessas retóricas dos 'redentores' de plantão?".

Enfim, em cada um destes breves estudos, com seus estilos e ênfases (e também lacunas), encontramos análises consistentes do discurso oficial sobre a relação entre desemprego e educação. Análises que precisamente por serem consistentes denunciam de forma inequívoca as escolhas (e alianças) de um governo que se diz de todos e que, 
para muitos, ainda precisa ser desmascarado.

\section{Estudo I}

\section{A naturalização do desemprego estrutural}

Jane Barros Almeida[2]

\section{A naturalização da crise}

A entrevista realizada pelo jornal "O Globo" em seis de Março de 2006 retrata de maneira bastante clara a política implementada pelo Ministério do Trabalho em conseqüência de uma política mais ampla executada pelo governo federal. Os argumentos, o eixo de prioridades e recomendações apresentadas pelo então Ministro do Trabalho Luiz Marinho [3] explicitam a lógica neoliberal. Para melhor entender essa caracterização, é necessário entendermos o que é neoliberalismo. Segundo Armando Boito em Política neoliberal e sindicalismos no Brasil, para analisar a política neoliberal é extremamente necessário compreender em que consiste a ideologia neoliberal. Para este,

A ideologia contemporânea é, essencialmente, um liberalismo econômico, que exalta o mercado, a concorrência e a liberdade de iniciativa empresarial, rejeitando de modo agressivo, porém genérico e vago, a intervenção do estado na economia. (1999, p.23).

$\mathrm{Na}$ tentativa de complementar a tese de Boito, podemos afirmar que para que o objetivo seja alcançado, ou seja, para que o Mercado seja o concentrador do poder de fato, é necessário naturalizar e desistoricizar as relações sociais. É sob este prima, que o ministro diagnostica o cenário de crise estrutural e aponta as possíveis soluções.

A crise do trabalho assalariado, mesmo que não diretamente, é evidenciado por Marinho ao identificar que o trabalho no mercado 'formal' está datado e nos apresentar as novas alternativas de trabalho. Diagnostica também a diminuição de postos de trabalho no setor industrial onde predominam os trabalhos do tipo 'tradicional', curiosamente isso ocorre na década de 90, contudo o ministro não se dedica a identificar as causas de tal fato, apenas ressalta a positividade com o avanço nos setores de serviços. Segundo Marinho, "No Brasil, na década de 90, observou-se crescimento da importância relativa dos serviços no total de empregos. Tal fato se explica, também, pelo fraco desempenho da produção industrial do começo da década de 90 até 2003 (até o início do Governo LULA!). Assim, as ocupações ligadas ao setor de serviços vêm tendo e devem continuar a ter desempenho bastante favorável em um futuro próximo".

Essa forma fatalista de expor o problema evidencia a naturalização do sistema capitalista, 
ou seja, explica-se o aumento de emprego no setor de serviços em relação à diminuição do mesmo no setor industrial, além de não representar um aumento real, não questiona e tão pouco menciona as razões de tal deslocamento. Sendo assim, a face "criadora" do capitalismo, além do aumento relativo do emprego nos setores de serviços, apresentaria novas possibilidades e alternativas para os trabalhadores: como o empreendedorismo, os pequenos negócios e a economia solidária. Todos estes são formas e sistemas de trabalho precarizados, pois, como bem cita Marinho, distinguem-se do trabalho de tipo 'tradicional', com carteira assinada, direitos assegurados, etc.

Outro elemento apresentado por Luiz Marinho é que o problema do desemprego geraria novas possibilidades e alternativas de modo que a falta de trabalho para 'alguns' aparece de maneira meramente conjuntural, diante da não adaptação dos trabalhadores frente à nova realidade. É uma tentativa de silenciar a histórica luta dos trabalhadores pelos seus direitos e melhores condições de trabalho e colocar a necessidade de adaptação da sociedade, sobretudo dos trabalhadores, diante das novas exigências do mundo contemporâneo como sendo um processo natural, a-histórico e, sobretudo, urgente. David Harvey defende a tese de que vivemos hoje um período de acumulação flexível do capital, onde esses elementos, como o falta de emprego, a desarticulação das organizações de classe, o discurso da qualificação, fazem parte de uma articulação racional que tem como objetivo manter o atual padrão de modelo de acumulação capitalista,

A acumulação flexível parece implicar níveis relativamente altos de desemprego estrutural (em oposição ao friccional), rápida destruição e reconstrução de habilidades, ganhos modestos (quando há) de salários reais e o retrocesso do poder sindical... (1996, p.141).

Através dos seus 'palpites' sobre os cursos que estão na 'ordem do dia' e a necessidade de qualificação e requalificação dos trabalhadores, uma 'reconstrução de habilidades', Luiz Marinho delineia as exigências do capital necessárias para a manutenção do sistema, isso inclui, necessariamente, o controle dos trabalhadores e das suas organizações de classe, como é o caso dos sindicatos. Isso ocorre, pois, através das exigências de requalificação, ou maior qualificação, desloca-se o problema central. A questão deixa de ser a inexistência e a impossibilidade do pleno emprego, e passa a ser a falta de requisitos necessários para se adaptar a nova realidade que se configura. A individualização do problema culpabiliza o trabalhador pela sua situação de desempregado na medida em que o mesmo, se parar de estudar e se reciclar, não terá mais o seu emprego garantido, colocando as negociações coletivas em segundo plano. O indivíduo passa a ser responsável pela sua trajetória de sucesso ou fracasso. "Para quem está empregado, Marinho faz um alerta: não se pode mais parar de estudar. E, para os jovens, cita os setores de serviços e de alta tecnologia, inclusive no nível técnico, como os mais promissores."

Ou seja, o desemprego em massa não é visto pelo ministro do trabalho, ex-presidente da CUT, como estrutural[4], inerente ao sistema capitalista, mas sim como um problema de falta de 'qualificação' e 'readaptação' diante das novas transformações no mundo do 
trabalho. Neste sentido não cabe aos trabalhadores se organizarem para garantirem mais trabalhos através da diminuição do lucro dos capitalistas e sim lutar pela sua qualificação. Um discurso perfeitamente neoliberal e a-histórico que cumpre um papel desmobilizador, individualizando o problema e desarticulando os sindicatos.

Um outro elemento capaz de confirmar a nossa tese, de que o discurso neoliberal é explicitado na entrevista, é evidenciado a partir das parcerias entre capital e trabalho, através das alianças estabelecidas com o sistema S (SESI, SENAI) a fim de possibilitar a requalificação do trabalhador. Com isso Marinho apresenta os parceiros dos trabalhadores e do Estado capazes de garantir a tarefa de qualificar os trabalhadores às novas exigências do mundo do trabalho, o capital, onde o sistema S representado pela CNI (Confederação Nacional da Indústria) assume um papel de centralidade. Este tema não aparece por acaso no discurso do entrevistado, mas sim com uma intencionalidade clara de não responsabilidade total do Estado. Todavia, como salienta Celso Ferreti, esta aliança conta também com o apoio dos sindicatos,

Os cursos de formação profissional raramente eram produzidos pelos sindicatos, que preferiam recorrer ao SENAI ou ao SENAC para tal fim (2002, p.101).

Quando questionado sobre o custo alto destes programas de formação e requalificação do sistema S, Marinho responde, "Vira e mexe temos essa reclamação, sim. Mas essa é uma discussão ainda a ser feita. De qualquer forma, é bom lembrar que o sistema S presta um grande serviço". A fidelidade ao capital não permite uma crítica, tão pouco um questionamento mesmo que superficial! E reafirma, “... O maior desafio do ministério hoje é elevar a escolaridade e, depois, qualificar o trabalhador." Ou seja, o problema do desemprego é centrado na desqualificação dos trabalhadores, o que justifica as ações do Ministério, em um mundo globalizado e neoliberal, em buscar parcerias com a iniciativa privada e utilizar verbas do FAT para possibilitar tal qualificação. A naturalização dos problemas sociais, como o desemprego, faz com que a conclusão coletiva seja a de que os trabalhadores devem se qualificar a fim de criar condições para a sua empregabilidade e isso só é possível através dessa narrativa a-histórica e falaciosa.

\section{A empregabilidade como solução ao desemprego estrutural}

Este grande 'apelo' feito à educação é um dos elementos que revela o discurso neoliberal, no sentido em que ela oferece a empregabilidade, e que diante das exigências do mercado ela se faz mais que necessária, tanto para a garantia de continuidade de emprego quanto para conseguir um novo posto de trabalho. Isso vai ao encontro da teoria defendida por Gaudêncio Frigotto. Para este, estaríamos vivenciando um rejuvenescimento da teoria do capital humano, talvez com um invólucro mais 'social', mas de qualquer forma a educação manteria a sua função, no que concerne a primazia desta teoria[5], em potencializar a força de trabalho.

Morta definitivamente a promessa do pleno emprego, restará ao indivíduo (e não ao 
Estado, às instancias de planejamento ou às empresas) definir suas próprias opções, suas próprias escolhas que permitam (ou não) conquistar uma posição mais competitiva no mercado de trabalho. A desintegração da promessa integradora deixará lugar à difusão de uma nova promessa, agora sim, de caráter estritamente privado: a promessa da empregabilidade (GENTILI, 2002, p.51).

E.K.Hunt, no seu livro, História do pensamento Econômico, apresenta os quatro conjuntos de esquemas institucionais e comportamentais do capitalismo, ou melhor, seus elementos principais e fundantes. O primeiro seria a produção de mercadorias, orientada pelo mercado; o segundo elemento a propriedade privada dos meios de produção; o terceiro a força de trabalho disponível no mercado, trabalho vivo; e por último e não menos importante o "comportamento aquisitivo, maximador, da maioria dos indivíduos dentro do sistema econômico" (1981, p.26). Podemos então, baseados no Hunt, afirmar, a partir do discurso do Ministro do Trabalho, Luiz Marinho, a necessidade material de exacerbação do individualismo na atual fase da acumulação capitalista representado através da idéia de empregabilidade.

Cabe aos trabalhadores a responsabilidade, como já mencionamos anteriormente, de garantir o seu emprego. O indivíduo é superdimensionado com o propósito de encobrir a crise do capital que há muito perdeu seu potencial criativo, acarretando uma maior competitividade onde o companheiro, o trabalhador ao lado, torna-se o maior inimigo, e o empregador, mais um parceiro. A própria noção de empregabilidade abarca uma totalidade de elementos beneficiador do capital. Segundo Gentili (2002), a redução dos encargos patronais, uma vez sendo responsabilidade do trabalhador arcar com os custos de formação, a flexibilização trabalhista, propiciada pelo Estado, e a formação profissional permanente, mediante o temor do desemprego, são elementos estruturantes da idéias de empregabilidade. Os que não estão buscando a empregabilidade, ou que não atendem os requisitos e necessidades do mercado são 'inempregáveis',

O conceito de "inempregável" parece traduzir, no seu cinismo, a realidade de um discurso que enfatiza que a educação e a escola, nas suas diferentes modalidades institucionais, constituem sim uma esfera de formação para o mundo do trabalho. Só que essa inserção depende agora de cada um de nós. Alguns triunfarão, outros fracassarão. (Gentili, 2002, p.55).

É interessante notar que a resposta para o desemprego, que é estrutural, se coloca no marco da incapacidade do trabalhador de não possibilitar o pleno emprego diante da sua fragilidade na formação. Contudo, este discurso não se sustenta mais. A educação vista como panacéia, como potencializadora de desenvolvimento, a partir da teoria do capital humano, capaz de levar um país ao desenvolvimento econômico, cai por terra ao analisar os recentes fenômenos ocorridos da Europa, nos EUA, ou seja, nos países centrais. A taxa de desemprego nestes países vem crescendo e a idéia de pleno emprego há muito já fora abandonada. A educação não foi capaz de garantir a solução para os problemas 
estruturais. Não possibilitou a paz, tão pouco o desenvolvimento econômico evidenciando e reafirmando a tese de Frigotto (1989), que o determinante vira determinado:

Enquanto a educação e tida, na ótica do capital humano, como fator básico de mobilidade social e do aumento da renda individual, ou fator de desenvolvimento econômico, nestas análises, o 'fator econômico', traduzido por um conjunto de indicadores sócio-econômicos, é posto como sendo o maior responsável pelo acesso, pela permanência da trajetória escolar e pelo rendimento ao longo dessa trajetória. $O$ que é determinante vira determinado. "Ou seja, a escolarização é posta como determinante da renda, de ganhos futuros, de mobilidade, de equalização social pela equalização das oportunidades educacionais (tese básica do modelo econômico concentrador)...”. (1989, p.51)

Frigotto nos mostra como este discurso que se baseia na idéia da educação, no que diz respeito ao capital humano, como potencializadora do desenvolvimento social não se sustenta, pois a mesma é determinada pelas relações de classes estabelecidas pelas relações de produção da sociedade. Ou seja, as oportunidades em garantir melhores postos de formação estão intimamente relacionadas com o poder econômico de cada um na sociedade, este determinado pelo seu local na produção, pelas relações sociais de produção. Este trecho citado ainda se remete a noção de um modelo econômico concentrador, um Estado forte e centralizador. Contudo no seu livro Educação e a Crise do Capitalismo Real (1999), Frigotto fala sobre o rejuvenescimento da teoria do capital humano, como mencionamos anteriormente, como sendo um resgate desta teoria em um novo contexto histórico, em um mundo globalizado, neoliberal e extremamente individualista, um mundo que impõe a necessidade de 'requalificação', de 'novos saberes' e que forja novos conceitos diante da incapacidade de dar respostas eficazes à humanidade, como o de empregabilidade. Ou seja, um mundo que se apresenta como "pano de fundo" capaz de legitimar o discurso de Luiz Marinho.

No entanto, apesar da aparência fenomênica de estarmos em um mundo 'novo', que se apresentaria através de novas alternativas de trabalho e novas exigências de formação, este se revela como o mesmo velho mundo, da mesma velha ordem capitalista. As condições concretas e as relações sociais de produção não apresentaram mudanças substancias, ou radicais. E no que diz respeito ao Brasil, a "esperança que venceu o medo", vem sendo soterrada pelas estruturas "democráticas" e pelos seus intelectuais orgânicos, ou "ex-sindicalistas" orgânicos, que cumprem bem o papel de manutenção da ordem e sustentação da ideologia neoliberal.

\section{Referências Bibliográficas}

BOITO, Armando Junior. Política Neoliberal e Sindicalismo no Brasil. São Paulo: Xamã, 1999..

FERRETI, Celso João. Empresários, trabalhadores e Educadores: Diferentes olhares sobre a relação trabalho e educação no Brasil nos Anos Recentes In: LOMBARDI, José Claudinei (org.). Capitalismo Trabalho e Educação. Campinas: Autores Associados- HISTEDBR, 2002.

FRIGOTTO, Gaudêncio. A produtividade da escola improdutiva: um (re)exame das relações entre educação 
e estrutura econômico-social e capitalista. São Paulo: Cortez, Autores Associados, 1989.

Educação e a crise do capitalismo real. São Paulo: Cortez,1999.

GENTILI, Pablo. Três teses sobre a Relação Trabalho e Educação em tempos Neoliberais In: LOMBARDI, José Claudinei (org.) (2002). Capitalismo, trabalho e educação. Campinas, São Paulo: Autores AssociadosHISTEDBR, 2002.

HARVEY, D. Condição pós-moderna. Uma pesquisa sobre a origem da mudança cultural. São Paulo: Loyola, 1996.

HUNT, E. K. Prefácio. In: IDEM. História do pensamento Econômico. Rio de Janeiro: Campus, 1981.

\section{Estudo II}

\section{“O emprego não acabou, os trabalhadores estão desqualificados": os novos atributos pessoais demandados pelo capital}

Mônica Ribeiro de Araújo[6]

A proposta de discutir a entrevista concedida à jornalista Léa Cristina (O Globo 06/03/2006) com o ex-presidente da Central Única dos Trabalhadores (CUT), agora Ministro do Trabalho, Senhor Luiz Marinho, nos conduz a recuperar não apenas questões ligadas ao título da referida entrevista: "o emprego não acabou”, mas, e, sobretudo, nos força a recobrar, mesmo que parcialmente, questões estreitamente atreladas às políticas educacionais na construção das novas qualidades pessoais demandadas pelo capital. Inicialmente, o citado ministro discorre acerca do empreendedorismo tentando justificar que o advento das novas tecnologias não elimina o emprego formal, porém, concorda que existe um aumento das ações de empreendedorismo, segundo ele, isto é um movimento criado não pela falta de emprego formal, mas pelo crescimento do mercado.

Temos muitas ações de empreendedorismo, os novos e pequenos negócios, a economia solidária, a indústria de artesanato... Todas são oportunidades que estão sendo criadas.

O interessante no discurso cínico do ministro é a tentativa de nos convencer que o emprego formal não acabou, que existem, inclusive, setores em que falta mão de obra qualificada.

A qualificação se tornou um fator fundamental para a melhor inserção e a manutenção do trabalhador no mercado, assim como para obtenção e manutenção dos postos de melhor qualidade... [sendo que] o maior desafio do ministério hoje é elevar a escolaridade e, depois, qualificar o trabalhador. Precisamos de um processo contínuo de qualificação, de formação: acadêmica e técnica. E esse é um desafio de governo, não só do Ministério do Trabalho. Precisamos recuperar as escolas técnicas... Vale a pena investir no setor de serviços, na área da educação; e na indústria... em profissões como mecatrônica, por 
exemplo, não conheço ninguém formado que esteja desempregado. Setores de alta tecnologia também são recomendáveis diante da escassez de mão-de-obra qualificada a qualificação se tornou um fator fundamental.

Neste projeto societário, a educação aporta como condição para sustentação do modo de acumulação vigente - o capitalismo - que busca, na escola, suporte para conseguir adestrar o homem às condições necessárias do mercado. Outrossim, o conhecimento, o saber, a educação, abriga conteúdos de interesses da classe burguesa, na busca pela manutenção da dominação e reprodução dos seus valores e visão de mundo.

As políticas educacionais desenvolvidas pelo Governo Lula como parte das políticas sociais, alicerçam-se para a conformação de um sistema propagador da efetivação das exigências do modelo neoliberal, direcionado para uma concepção produtivista, com a função de ampliar as habilidades de conhecimentos e valores de uma administração de qualidade, definidas sob o signo do mercado, que limita a educação do trabalhador, tão somente, ao seu enquadramento no novo perfil prescrito pelo mercado do trabalho. (Ribeiro, 2006, p. 11).

As transformações ocorridas no mundo do trabalho têm marcado profundamente as mudanças no processo de formação de aptidões/competências/qualificações para o trabalho no novo modelo produtivo. A educação/escola (re) surge, no discurso burguês, como parte principal para o desenvolvimento requerido pela nova economia que separa os países tecnologicamente industrializados dos países em vias de desenvolvimento no cenário internacional.

As qualificações exigidas no interior desse "novo modelo produtivo", representado pelo modelo empresarial japonês, contrastam fortemente com aquelas relacionadas com a lógica taylorista de remuneração, de definição de postos de trabalho e de competências: trata-se da capacidade de pensar, de decidir, de ter iniciativa e responsabilidade, de fabricar e consertar, de administrar a produção e a qualidade a partir da linha, isto é, ser simultaneamente operário de produção e de manutenção, inspetor de qualidade e engenheiro. (Hirata, 1994, p.130).

Para tanto, o trabalhador deve participar de um processo contínuo de qualificação voltada para o mercado de trabalho, o que conta com a "contribuição" do Sistema ${ }^{[7]}$ para a requalificação dos trabalhadores que já concluíram os estudos. Cabe ressaltar, aqui, a opção por uma formação fragmentada em detrimento da formação integral, qual seja a mudança na educação de base.

Nos debates dos Organismos Internacionais acerca da problemática do desenvolvimento econômico, sobretudo nos países de capitalismo dependente, encontra-se "preocupados" com a educação. Atribuem à educação "novas solicitações" cujo objetivo é maior produtividade, qualidade e competitividade no mercado, requisitos exigidos pela "nova"

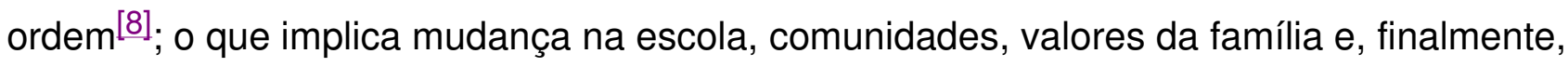
no mundo do trabalho. 
Destarte, como bem explicitou o Sr.Luiz Marinho, não falta emprego, falta mão-de-obra qualificada. O governo não tem responsabilidade com o crescente índice de desemprego, mas uma vez, a culpabilidade é do trabalhador que não foi competente o suficiente para se qualificar e possuir os novos atributos pessoais requeridos pelo mercado. Ainda segundo o entrevistado, o governo, inclusive, preocupado com a ausência da "mão-de-obra de qualidade", criou o Programa Universidade para Todos (PROUNI), que segundo o mencionado ministro, concedeu 112 mil bolsas integrais e parciais ${ }^{[9]}$ no primeiro processo seletivo e, neste ano, oferecerá 130 mil bolsas em 1.142 instituições de ensino superior privado.

É imperativo registrar que, apesar do estudante ter bolsa integral, o ingresso aos cursos mais procurados, tais como Medicina, Odontologia, Veterinária e em algumas capitais o curso de Direito, fica restrito a nota de corte[10]. Todavia, o governo federal está fazendo a parte dele, está distribuindo bolsas para as universidades particulares e sucateando, a cada ano, as universidades públicas com o fito de torná-las privadas, para que o governo possa participar do mais novo meganegócio: a educação.

À medida que surgem novas demandas do mercado, requer-se um novo perfil de trabalhador com novas aptidões técnicas e pessoais. São condições impostas, confirmando uma lógica que privilegia o capital.

As aptidões técnicas requeridas do trabalhador insere-se no projeto de educação a nível mundial determinadas na Conferência Mundial sobre Educação para Todos realizada em Jomtien, Tailândia, de 5 a 9 março de 1990, cuja meta "viável" é a Satisfação das Necessidades Básicas de Aprendizagem (NEBAS), quais sejam, saberes necessários para atuar em determinada área - saber ler, escrever, fazer cálculos, se expressar e, ter noções sobre informática. Contudo, o mais importante são as aptidões pessoais do trabalhador.

O trabalhador deve possuir espírito de equipe, iniciativa, sociabilidade, ser comunicativo, criativo, responsável, ter autonomia, disciplina, saber se adaptar as mudanças, ter espírito cooperativo, ter comprometimento, ser leal, saber pensar e saber tomar decisões rápidas.

O Estado neoliberal desenvolve o individualismo em detrimento do coletivismo, contraditoriamente, o trabalhador para se manter em seu posto de trabalho deve renunciar seus egoísmos internos, interesses pessoais e subordiná-los ao interesse coletivo da equipe. Neste cenário, a questão da educação está presente no discurso de segmentos distintos da sociedade. A educação básica passa a ser o ponto estratégico na promoção do desenvolvimento das habilidades requeridas ao trabalhador.

A educação oferecida pelo Estado passa a ser rotulada de ensino de baixa qualidade e incapaz de contribuir com o crescimento da economia. Há quase um consenso quando se trata de apontar que o sistema educacional brasileiro não vem respondendo às necessidades do novo perfil de qualificação da mão-de-obra. Dada essa sentença e de acordo com as instruções dos organismos internacionais, a esfera civil deve 
responsabilizar-se pela educação. Adentram no cenário educacional, os empresários. Avaliada como moeda de peso, mercadoria de ponta, a educação, quão mais ajustada às demandas do mercado, melhor poderá contribuir para que os indivíduos obtenham sucesso na corrida - sempre salutar, conforme supõem - pelas melhores oportunidades de vida e de trabalho. (Jimenez, 2000, p.96)

Cabe ao Estado além de colaborar com a iniciativa privada, realizar ações de caráter compensatório. Como parte da política de compensação dos ajustes econômicos foram criadas verbas destinadas aos programas sociais como, Fome Zero, Bolsa Família, Bolsa Escola, entre outros.

Neste contexto, as iniciativas privadas, as empresas, materializaram suas idéias no campo educacional e responsabilizando-se em educar e transmitir as habilidades formais necessárias para o novo mercado. São criados os Centros de Ensino Superior e os Centros Tecnológicos.

É também, neste contexto, que se insere a determinação de um número crescente de empresas que assumem para si a tarefa de promover a escolarização de seus trabalhadores, levando a escola para o chão de fábrica.

Novas relações entre o público e o privado são firmadas com o intento de "sanar" os problemas referentes à educação.

Não resta dúvida de que no campo educacional tudo tem sido muito alterado. Nunca antes o Brasil, o Estado interveio tão rápido e organicamente para formar um novo tipo de trabalhador e de homem, através da aparelhagem escolar... (Neves, 1990, p. 133)

Destarte, um conjunto de ações busca a melhoria da qualidade do sistema educacional voltadas para a diminuição da repetência, evasão escolar e a implantação do sistema de aceleração escolar, para o aluno que está fora da faixa etária, receber de forma aligeirada, os rudimentos básicos dos estudos. Esses são aspectos que colaboraram para a redução das taxas de evasão, repetência e ainda, não podemos esquecer, prepara, em tempo recorde, para o mercado de trabalho.

Neste contexto, temos algumas questões. A aparelhagem escolar deve articular-se ao interesses do capital, submetendo a formação do trabalhador às competências e habilidades requeridas pelo mercado e pelo modelo de acumulação flexível do trabalho do capital, que desvincula o trabalho manual do trabalho intelectual? Não deve a Escola articular-se aos interesses da classe trabalhadora, para que esta tenha o que sempre lhe fora negado, ou seja, a articulação entre teoria e prática - imprescindível na luta pela superação da lógica do capital e na construção de uma sociedade onde homens organizados possam ser livres para trabalhar associados na busca de desenvolver todas as suas potencialidades?

Neste sentido, torna-se fundamental retomar o debate sobre a concepção politécnica de educação na qual intelectuais da área de educação entendem o trabalho humano como 
categoria ontocriativa, princípio educativo mediado pela tecnologia. $\mathrm{E}$, o ensino de boa qualidade é o que propicia aos alunos: superar o estreito vínculo de seus interesses pessoais imediatos; entender as relações do homem com a natureza e as relações dos homens entre si; perceber o sujeito humano como autor e artífice do seu mundo e de sua história. É, enfim, o ensino que propicia a formação integral da personalidade do sujeito histórico (Saviani, 1997).

\section{Referências Bibliográficas}

HIRATA, H. Da polarização das qualificações ao modelo da competência. In Ferretti C. et al. (orgs) Novas Tecnologias, trabalho e educação: um debate multidisciplinar- Petrópolis: Vozes, 1994

JIMENES, S.V. (Org) Trabalho e educação: uma intervenção crítica no campo da formação docente. Fortaleza: Demócrito Rocha: 2001

NEVES, L.M. W, Educação: um caminhar para o mesmo lugar? In LESPAUBIN, Ivo (Org). O desmonte da nação: Balanço do governo FHC. (2 ${ }^{\mathrm{a}}$ ed). Petrópolis: Vozes, 1999.

RIBEIRO, Mônica. A (con) formação dos trabalhadores no Governo Lula sob o signo do mercado. 2006. (mimeo)

SAVIANI, N. Educação brasileira em tempos neoliberais. Princípios, № 45, São Paulo: Anita Garibaldi, 1997. (p.52-60)

\section{Estudo III: \\ É possível reproduzir a vida contando apenas com um emprego no mercado formal? Discutindo estratégias de trabalho e de sobrevivência}

Ana Cristina Costa dos Santos de Castro[11]

No jornal O Globo de 6 de março deste ano de 2006, o atual ministro do trabalho, o Sr. Luiz Marinho, concedeu uma entrevista a jornalista Léa Cristina, sob o título "O emprego não acabou". Nesta reportagem, o referido ministro fala sobre o atual momento econômico, o mercado de trabalho e outros temas da mesma ordem.

É curioso observar - isso para não dizer que é perverso - como o discurso vai se configurando sobre bases contraditórias e de concepção neoliberal, embora o verniz tente dar um tom conciliatório entre capital/trabalho.

Um dos pontos levantado pelo ministro diz respeito à educação. Quanto a isso, ele afirma que não se pode mais parar de estudar e segundo suas próprias palavras

a qualificação se tornou um fator fundamental para a melhor inserção e manutenção do trabalhador no mercado, assim como para obtenção e manutenção dos postos de melhor qualidade... [sendo que] o maior desafio do ministério hoje é elevar a escolaridade e, depois, qualificar o trabalhador. Precisamos de um processo contínuo de qualificação, de formação: acadêmica e técnica. E esse é um desafio de governo, não só do Ministério do Trabalho. Precisamos recuperar as escolas técnicas... Vale a pena investir no setor de 
serviços, na área da educação; e na indústria... em profissões como mecatrônica, por exemplo, não conheço ninguém formado que esteja desempregado. Setores de alta tecnologia também são recomendáveis diante da escassez de mão-de-obra qualificada.

Diante de todas as contradições impostas pelo capitalismo e acirradas pelas políticas neoliberais, cremos ser necessário uma reflexão profunda acerca da relação trabalhoeducação, na tentativa de aproximar os estudos dessa área da práxis pedagógica da escola e mais especificamente da escola pública, pois é ela que atende aos filhos dos trabalhadores. É certo que a escola para todos não resolve os problemas provenientes da contradição capital-trabalho. Esta é inerente à própria sociedade capitalista e, por isso, só resolveremos o problema da dualidade social com uma mudança estrutural, pois a escola, na maioria das vezes, reproduz a dualidade existente na sociedade. Entretanto, algumas questões precisam ficar todo tempo "martelando": Educação para que tipo de homem? Para que mundo do trabalho?

A ilusão da teoria do capital humano se mostra com todo fôlego nas palavras do ministro. Wallerstein $(2001$, p.108, 109) chama atenção que embora não se possa negar de todo que haja uma correlação entre os anos de educação e renda recebida, essa expansão da educação também produziu um aumento de pré-requisitos educacionais para o emprego, a tão falada qualificação. Essa exigência desleal recai sobre o trabalhador como se o desemprego fosse culpa sua e não uma condição estrutural do sistema capitalista. Ou seja, mesmo que fosse possível a todos os trabalhadores se qualificarem como exige o mercado formal de trabalho, ainda assim não haveria emprego para todos.

O ministro também afirma que o avanço da tecnologia não elimina o emprego. Entramos no terceiro milênio e todo o avanço tecnológico que a ciência proporcionou não foi capaz de amenizar a miséria, a fome e as desigualdades profundas entre os seres humanos. Assim nos damos conta do quanto o conhecimento científico é paradoxal, quanto mais geramos ciência, quanto mais se agiganta diante de nós a ignorância; todos os benefícios produzidos pela ciência trouxeram consigo, de certa forma, um ônus que ainda não soubemos solucionar e quanto mais aumentam os poderes da ciência, mais nos tornamos impotentes diante dela.

Isso porque o capitalismo, sendo intrinsecamente contraditório, quanto mais produz conhecimento e riquezas, mais aumenta a nossa perplexidade diante da própria sobrevivência dos seres humanos e da natureza, ou seja, do próprio planeta. Assim, o aprofundamento das desigualdades tem produzido milhões de pessoas que vivem no limite entre a pobreza e miserabilidade. Isso porque o modelo neoliberal de acumulação de capital está assentado, dentre outros, na

desregulamentação e desestruturação da sociedade salarial, cujas manifestações são - 
além do desemprego - o trabalho temporário, os baixos salários, a terceirização e outras formas de flexibilização e precarização do trabalho que corroboram com a precarização da própria vida. (Tiriba, 2004, p.75)

A questão central a que queremos estar atentos é essa pobreza. É preciso entender esses seres humanos na sua materialidade. Marx chama a atenção para

o motivo que impulsiona e o objetivo que determina o processo de produção capitalista é a maior autovalorização possível do capital, isto é, a maior produção possível de mais-valia, portanto, a maior exploração possível da força de trabalho pelo capitalista. (1983, p.263)

Na reportagem, o ministro afirma também que o mercado de trabalho não mudou tanto quanto dizem os analistas, mas que ficou mais complexo. Embora parte dessa afirmação seja real - o mercado realmente está mais complexo - há que se questionar essa argumentação, visto que ela se encaminha para a discordância da afirmação de que o emprego tradicional, o da carteira assinada, acabou e ainda lista o empreendedorismo, os pequenos negócios e a economia solidária como novas opções de trabalho.

Entretanto, o que o ministro não discute é o desemprego como questão estrutural da sociedade capitalista. Nas palavras de Mészáros,

a tendência devastadora do desemprego crônico hoje afeta até mesmo os países capitalistas mais adiantados. Ao mesmo tempo, também as pessoas ainda empregadas naqueles países têm de suportar a piora de suas condições materiais de existência, o que é admitido até mesmo pelas estatísticas oficiais. (2003, p.27).

Se nos países nos quais o Estado de Bem Estar Social realmente aconteceu os trabalhadores vêm enfrentando todo tipo de dificuldade, que diremos do Brasil, no qual as ações relativas aos direitos sociais são tímidas? A política econômica e social neoliberal afetou os interesses dos trabalhadores ao priorizar os interesses do capital financeiro, conseguindo isso à custa do arrocho das verbas sociais. Quanto a isso Boito Jr. nos alerta que

não se pode analisar a política social, isto é, as medidas governamentais em áreas como saúde, educação, previdência, saneamento, habitação e transporte, separadamente da política econômica. A pobreza não é um dado natural com o qual se deparam os governos neoliberais; ela é produzida pela própria política econômica neoliberal, que reduz o emprego e os salários e reconcentra a renda. (1999, p.77)

Outro dado importante a ser destacado, em relação à precarização do trabalho, é a questão da informalidade. Uma "nova informalidade"[12] se generaliza, transformando a dicotomia entre trabalho formal e trabalho informal numa falácia, pois "a formalidade e a 
informalidade coexistem, subsidiam-se, interpenetram-se e são indissociáveis" (Malaguti, 2000 , p. 101). A legalidade ou ilegalidade é outro discurso discutível, pois são usados muitos subterfúgios para burlar as leis trabalhistas, e os trabalhadores, diante de tanto desemprego, aceitam propostas, que além de ilegais são imorais, com medo de perderem seus empregos. Como nos diz Malaguti, "a carteira de trabalho assinada nada mais é do que um 'documento de fachada', com pouca ou nenhuma relação com o quotidiano de trabalho ou com os direitos dos trabalhadores. Logo, tudo se passa à margem da legislação trabalhista: na informalidade" (ibidem, p.100).

Os trabalhadores, ao reproduzirem suas vidas, o fazem contando, em grande parte, com rendimentos não salariais que são, na verdade, os primeiros dos complementos. (Morice apud Malaguti, 2000, p.129). Por transitarem entre a situação de "trabalhador assalariado" e de "trabalhador independente", seu status de trabalhador origina-se "de uma experiência de vida seguidamente complexa e multifacetada, cujas variantes ocasionais interpenetramse, definido e redefinindo o que agora se faz e, seguidamente, do que pretende fazer" (Malaguti, 2000, p.166).

Essa distinção feita nas pesquisas entre trabalhadores empregados e desempregados decorre de um grande problema que reside na não diferenciação entre trabalho e emprego, pois

ao reduzir o conjunto dos trabalhadores à condição de "empregados" e "desempregados", os economistas circunscrevem a produção social da vida às regras capitalistas de produção, sugerindo que o trabalho é, necessariamente, uma mercadoria que deve ser posta à venda no mercado. (Tiriba, 2004, p.79).

Levando-se em conta a reprodução ampliada da vida, não limitando apenas à biológica, os setores populares são impelidos à criação de diversas estratégias de trabalho e de sobrevivência. Diante disso, reivindica-se a economia popular como um conceito que seja capaz de dar conta dessas formas de sociabilidade que escapam à lógica capitalista. Participam da economia popular não apenas os desempregados, mas todos os trabalhadores que, embora assalariados, se vêem obrigados, devido à precarização de seus trabalhos, a lançar mão de inúmeras estratégias que lhes garantam melhores condições de vida.

O atual momento de reestruturação econômica acirrou a condição de desemprego estrutural. Isso significa um número cada vez maior de pessoas vivendo na pobreza e com possibilidades cada vez maiores de se situarem em faixas de miserabilidade. Assim, com um número cada vez mais significativo de pessoas vivendo à margem do mercado (assalariado) de trabalho, o tema da pobreza e da luta pela sobrevivência se situa num campo importantíssimo de estudo da satisfação das necessidades mais imediatas e de 
condições de vida.

Algumas pesquisas já trabalham com a questão da reprodução dos setores populares. Cecília Cariola, em Sobrevivir em la pobreza: el fin de uma ilusión, afirma ser necessário mostrar os processos que supõe o viver a pobreza. A referida autora utiliza-se do conceito de estratégia de sobrevivência como instrumental analítico que permite captar esse processo em todas as suas dimensões e complexidade:

Hemos recurrido a un enfoque integrador operacionalizado por medio del concepto de estrategia de sobrevivencia que aborda la reproducción biológica, material y social desde el plano doméstico en forma articulada com o plano colectivo. Concepto que adquiere una connotación social específica al estar aplicado a los sectores populares urbanos, en tanto sectores subordinados en sociedades concretas como las impone su pertenencia de clase. (Cariola, Apud Cariola, 1992, p.23).

$\mathrm{Na}$ esteira do estudo sobre a reprodução dos setores populares, encontramos o conceito de "economia popular" que se diferencia do conceito tradicional de "economia informal", pois se refere "a um conjunto de atividades econômicas e práticas sociais desenvolvidas pelos setores populares no sentido de garantir, com a utilização da própria força de trabalho e dos recursos disponíveis, a satisfação de necessidades básicas, tanto materiais e imateriais" (Tiriba e Icaza, 2003, p.101). Entretanto, isso se dá numa dimensão que ultrapassa a simples aquisição de ganhos materiais e está intimamente ligado à reprodução ampliada da vida. Contrapondo-se à lógica dos valores capitalistas, serão a reciprocidade, a cooperação e a solidariedade que nortearão as relações estabelecidas entre os sujeitos da economia popular, que criam estratégias de trabalho e de sobrevivência

que visam não apenas à obtenção de ganhos monetários e excedentes que possam ser trocados no mercado, mas também à criação das condições que lhes favoreçam alguns elementos que são fundamentais no processo de formação humana, como a socialização do saber e da cultura, saúde, moradia, etc. (ibidem).

Dessa forma, para além da simples geração de renda, os setores populares "se organizam em atividades da economia popular, em ações espontâneas de solidariedade entre familiares, amigos e vizinhos e também nas ações coletivas organizadas no âmbito da comunidade, objetivando a melhoria da qualidade de vida" (ibidem). As autoras citam como exemplo os mutirões para limpeza de valões, para recuperação de casas ou parte delas, para aterramento da rua etc.

Assim, afirmar que o mercado se complexificou, mas fechar os olhos para a situação de milhões de brasileiros que vivem sob condições de vida as mais precárias possíveis, é no mínimo má fé. Como já foi dito, não há possibilidade de emprego para todos dentro dos moldes capitalistas. Além disso, a enorme concentração de renda provoca um fosso 
profundo entre aquela mínima parcela que detém o poder econômico e a grande maioria desprovida de quase tudo.

Referências Bibliográficas

BOITO JR. Armando. Política neoliberal e sindicalismo no Brasil. São Paulo: Xamã, 1999.

CARIOLA, Cecília. La reproducción de los sectores populares urbanos: uma proposta metodológica. In: CARIOLA, Cecília. (coord.) Sobrevivir en la pobreza: el fin de una ilusión. Caracas: Cedes/Nuevas Sociedad, 1992.

MARX, Karl. O Capital: crítica da economia política. São Paulo: Abril, 1983. (Coleção Os Economistas).

MALAGUTI, Manoel Luiz. Crítica à razão informal. A imaterialidade do salariado. São Paulo: Boitempo; Vitória: EDUFES, 2000.

MÉSZÁROS, István. O século XXI: socialismo ou barbérie? São Paulo: Boitempo Editorial, 2003.

Tiriba, Lia. Ciência econômica e saber popular: reivindicar o "popular" na economia e na educação. In: Tiriba, Lia e PICANÇO, Iracy (org). Trabalho e Educação. Arquitetos, Abelhas e Outros Tecelões da Economia Popular Solidária. São Paulo: Ed. Idéias e Letras, 2004.

e ICAZA, A. M. S. Economia Popular. In: CATTANI, Antonio David (org). A outra economia. Porto Alegre: Veraz, 2003.

WALLERSTEIN, Immanuel. Capitalismo histórico e Civilização capitalista. Rio de Janeiro: Contraponto, 2001.

\section{Estudo IV: \\ "O emprego não acabou": retórica?}

Zuleide Simas da Silveira[13]

"Vivemos num mundo conquistado, desenraizado e transformado pelo titânico processo econômico e tecnocientífico do desenvolvimento do capitalismo, (...) O futuro não pode ser uma continuação do passado" (Hobsbawm, 2005).

\section{1. "O emprego não acabou"}

Elaboro a análise da entrevista do Sr. Marinho, a partir do pressuposto de que o trabalho em sua dimensão ontológica é categoria inerente ao ser social; o trabalho é, então, 
processo coletivo e social, dirigido por finalidades conscientes, resposta aos desafios da natureza na luta pela sobrevivência. Portanto, "cabe compreender o trabalho, em sua dimensão contraditória, em seu desenvolvimento histórico que o mostra com características específicas e determinadas pelos diferentes modos de relações sociais de produção. Na sociedade capitalista, o trabalho possui dupla dimensão: na primeira, é trabalho útil, possui valor de uso - satisfaz as necessidades básicas do homem, de uso particular; na segunda, é trabalho abstrato, cria valor de troca - necessário ao processo de reprodução do capital (Marx). Nesta última, o trabalho representa a sua forma histórica degradada e alienada" (Silveira, 2006, p.2).

O trabalho ficou mais complexo, mas não mudou tanto. O emprego de carteira assinada continua existindo. No mercado formal de trabalho, teremos emprego pelos próximos 50 anos, pelo menos. O avanço da tecnologia não elimina o emprego, no entanto, empreendedorismo, pequenos negócios, economia solidária, indústria do artesanato são novas opções e oportunidades que estão sendo criadas. Para se manter empregado, deve se manter estudando. As áreas promissoras são as de serviço e de alta tecnologia'.

Com estas afirmações, Luiz Marinho, ex-presidente da Central Única dos trabalhadores (CUT), e atual Ministro do Trabalho, afirma que o emprego está relacionado ao estágio de desenvolvimento econômico do país. Em um primeiro estágio, o crescimento da demanda de postos de trabalho no setor industrial seria incrementado, ao passo que a taxa de emprego no setor agrícola decresceria. Em patamar mais avançado de desenvolvimento, o setor de serviços passaria a requerer mais mão-de-obra em detrimento dos setores agrícola e industrial.

Estas palavras nos mostram não apenas a intensificação das contradições e antagonismos da sociedade em que vivemos, como, também, que o sistema social capitalista necessita cada vez menos de trabalho estável e cada vez mais de trabalho part-time, terceirizado, precarizado - em franco crescimento seja no setor primário, seja nos setores secundário e terciário. Neste sentido, Antunes (2005a) salienta que, na contemporaneidade, o trabalho é reconvertido em seu caráter transversal em trabalho e desemprego, trabalho e precarização, trabalho e gênero, trabalho e etnia, trabalho e nacionalidade, trabalho e ecologia, trabalho e corte geracional, trabalho e materialidade, trabalho e imaterialidade, trabalho e qualificação, trabalho e desqualificação (p. 25-6).

Assim sendo, busquei junto a instituições de pesquisa dados que pudessem oferecer subsídios a minha análise. Segundo a Pesquisa de Emprego e Desemprego, realizada pela Fundação Seade e Dieese, entre janeiro e fevereiro de 2006, a taxa de desemprego aberto cresceu de $9,5 \%$ para $10,2 \%$ ao passo que o desemprego oculto[14] passou de $6,2 \%$ para $6,1 \%$, resultando no aumento da taxa de desemprego total de $15,7 \%$ para $16,3 \%$. Neste período de tempo, 62 mil pessoas ficaram desempregadas em face de $51 \mathrm{mil}$ 
ocupações serem eliminadas, enquanto, apenas, 11 mil pessoas entraram no mercado de trabalho. O contingente de desempregados passou a ser estimado em 1 milhão e 646 mil pessoas (http://www.dieese.org.br/ped/sp/pedrmsp0206.pdf).

Dados do lbge informam que a produção industrial apresentou, em fevereiro de 2006, um quadro de resultados positivos em 11 das 14 áreas pesquisadas, na comparação com igual mês de 2005. Acima da taxa registrada em nível nacional $(5,4 \%)$ ficaram: Amazonas $(18,0 \%)$, Rio de Janeiro (9,9\%), Pará $(9,1 \%)$, Ceará $(8,8 \%)$, Bahia $(7,5 \%)$ e Minas Gerais (7,1\%). Com crescimento abaixo da média nacional, São Paulo $(5,1 \%)$, região Nordeste $(3,6 \%)$, Goiás (3,0\%), Pernambuco (1,2\%) e Espírito Santo (1,1\%). Três locais apresentaram recuo na produção: Santa Catarina (-0,2\%), Rio Grande do Sul $(-1,3 \%)$ e Paraná (-7,4\%). No indicador acumulado para o primeiro bimestre, 12 das 14 regiões pesquisadas registraram taxas positivas, exceto Rio Grande do Sul (-1,9\%) e Paraná ($6,8 \%)$. As indústrias do Amazonas, com 11,9\%, e as do Pará $(10,0 \%)$ mostraram ritmo de crescimento a dois dígitos, apoiadas, sobretudo, nos desempenhos favoráveis de material eletrônico, comunicações (televisores) e da indústria extrativa (minérios de ferro). Ceará $(9,3 \%)$, Rio de Janeiro (7,8\%), Bahia $(7,0 \%)$ e Minas Gerais $(6,1 \%)$ completaram o conjunto de estados com taxas superiores à média da indústria (4,2\%). Os demais estados tiveram os seguintes resultados: São Paulo $(3,4 \%)$, Pernambuco $(2,9 \%)$, região Nordeste $(2,7 \%)$, Espírito Santo (2,3\%), Goiás (2,2\%) e Santa Catarina (1,1\%). Observou-se que as áreas de maior dinamismo no primeiro bimestre do ano foram diretamente influenciadas por fatores relacionados à ampliação na fabricação de bens de consumo, ao desempenho positivo de setores produtores de bens de capital (itens associados à energia elétrica, informática e telefonia celular), e à fabricação de produtos tipicamente de exportação. Em comparação com o índice do último trimestre de 2005, o acumulado para janeiro-fevereiro de 2006 assinalou aceleração de ritmo em nível nacional (de 1,3\% para 4,2\%) em 12 dos 14 locais pesquisados. Esse movimento se deu de forma mais acentuada no Ceará (de 7,9\% para 9,3\%), Amazonas (de 1,9\% para 11,9\%) e Pará (de 3,9\% para 10,0\%). Em nível setorial, no total do país, 13 das 18 atividades apresentaram resultados negativos, sendo que as principais contribuições vieram de calçados e artigos de couro (-14,2\%), máquinas e equipamentos $(-8,4 \%)$ e madeira $(-14,3 \%)$. Em sentido contrário, alimentos e bebidas $(8,8 \%)$, máquinas e aparelhos eletroeletrônicos e de comunicações $(5,0 \%)$ e meios de transporte $(3,6 \%)$ representaram os principais impactos positivos.

(http://www.ibge.gov.br/home/presidencia/noticias).

Neste cenário, o Ministro do Trabalho, ao declarar que o emprego não acabou, se baseou em coletas de dados que expressam a aparência da realidade nacional; no entanto, não mostra como o emprego, no Brasil, está estruturado e como ocorre sua evolução; portanto, seu discurso revela enquanto esconde. De fato, segundo resultados estatísticos, o emprego cresceu, a produção industrial aumentou. Mas em que condições? A resposta encontra-se fundamentada na análise dialética da realidade brasileira. 
No Brasil, a política neoliberal dos anos de 1990 aprofundou algumas tendências já manifestas no final dos anos de 1980. A partir daí, os governos neoliberais passam a redesenhar o setor industrial de modo a reforçar o papel que a economia brasileira vinha desempenhando na divisão internacional do trabalho - fornecer matéria-prima para economias do capitalismo central, em contrapartida receber no mercado interno produtos manufaturados produzidos naqueles países. Ao passo que o setor de serviços urbanos, agora privatizados - energia elétrica, telecomunicações, transporte, etc. —, torna-se alvo de investimentos do capital de países centrais. Neste sentido, Boito Jr. (2002) afirma que a indústria na América Latina tem sido afetada pelo processo de desindustrialização e desnacionalização. "A desindustrialização possui dois aspectos: redução da participação relativa da produção industrial na produção total dos países latino-americanos e redução da participação relativa da produção metal-mecânica, de bens de capital, de instrumentos eletrônicos e de química fina no total da produção industrial"(p.42), atingindo, sobremaneira, setores que fazem uso do conhecimento tecnocientífico e, ainda, aqueles ligados aos ramos têxtil, de vestuário e calçados.

Boito Jr. (2002) afirma que este processo de desindustrialização é pouco visível. A expansão da indústria de material de informática, de produtos eletrônicos de consumo e de montadoras de automóveis são casos típicos da desindustrialização no Brasil. "A Zona Franca de Manaus é o carro-chefe desse processo, pois essa região transformou-se num parque de montagem de componentes importados, devido ao fato de as tarifas de importação, que foram reduzidas para todo país, serem menores ainda para a Zona Franca"(p. 43-4). Entretanto, a desindustrialização inclui o crescimento do setor industrial voltado para a transformação de recursos naturais exportáveis. Hoje, as indústrias que mais crescem são as de transformação de matéria-prima, como, papel e celulose, petroquímica, ferro e aço, azeites vegetais, farinha de pescado, conservas, sucos.

A partir da análise de Boito Jr., fica explicito que a taxa de crescimento de emprego no Brasil, no setor da indústria, ocorre em condições tais que, na divisão internacional do trabalho, cabe à maioria dos trabalhadores no Brasil o papel de montador, embalador, encanador, soldador, etc., enquanto que o Sr. Marinho repete, de certo modo, o que fora dito, também em entrevista, por João Jesus de Sales Pupo, diretor do Departamento Nacional de Mão-de-Obra do Ministério do Trabalho, no ano de 1972: "no Brasil não existe desemprego e sim falta de qualificação profissional que causa o subemprego"(Cunha, 1975, p.52). Deste modo, afinado ao pensamento da burguesia industrial, o Ministro Luiz Marinho torna a educação uma variável econômica; "a escolarização é posta como determinante da renda, de ganhos futuros, de mobilidade, de equalização social pela equalização das oportunidades educacionais"(Frigotto, 2001, p.51).

O entrevistado assinala ainda: "É preciso investir na formação de base, como o MEC está fazendo. E, com ajuda de convênios com prefeituras e entidades setoriais, investimos em 
unidades de qualificação nos setores aéreos e de metalurgia. Agora, faremos no setor naval, no Rio". Em relação a este último, o levantamento preliminar do Plano Setorial de Qualificação (Planseq) do Ministério do Trabalho e Emprego (MTE) constatou um déficit de 8.565 trabalhadores para a retomada da indústria naval nos estados do Rio de Janeiro e Pernambuco. Diante de tal quadro, busquei, então, no site do MTE, o significado do déficit mencionado no documento.

O Planseq, instituído em novembro de 2004, é uma das ações do Plano Nacional de Qualificação (PNQ), cujo objetivo é direcionar a qualificação profissional do trabalhador a partir da demanda do mercado de trabalho local. "A articulação ocorre com as ações de qualificação voltadas diretamente para as oportunidades concretas de geração de emprego e renda". Segundo o MTE, o Planseq Naval será desenvolvido em parceria com o Senai ao longo dos anos de 2006 e 2007. No Rio de Janeiro, serão qualificados 7.052 trabalhadores em oito categorias profissionais: encanador (1.287), mecânico ajustador (321), montador (1.108), pintor (335), soldador de estrutura (1.964), soldador de tubulação (1.223), mecânico montador (164) e caldeireiro (650). E, em Pernambuco, será necessário qualificar 1.513 pessoas para atender à demanda local nas ocupações de caldeireiro (194), montador (331), pintor (100), soldador de estrutura (580), soldados de tubulação (141) e encanador (167).

O site informa, também, que o Planseq atua em outros setores, como, metalúrgica, aeronáutica, turismo e doméstica. Estão em fase de negociação os planos das áreas de construção civil (Espírito Santo); de petróleo e gás natural, em cinco estados (Bahia, Rio de Janeiro, Pernambuco, São Paulo e Paraná), e de agricultura familiar, no Pará. (http://www.mte.gov.br/Noticias)

Cabe ressaltar que, no Governo Lula, outros programas de qualificação profissional de nível básico vêm sendo desenvolvidos, em parceria com o empresariado, a exemplo do Programa de Mobilização da Indústria Nacional de Petróleo (Prominp), promovido pelo Ministério das Minas e Energia em parceria com a Secretaria de Petróleo e Gás Natural. O Prominp tem o objetivo de qualificar mão-de-obra para atuar na produção de petróleo e gás natural, transporte marítimo, dutoviário, refino e distribuição de derivados, cuja finalidade é "maximizar a participação da indústria nacional de bens de serviço, em bases competitivas e sustentáveis, na implantação de projetos de óleo e gás no Brasil e no exterior" (http://www.prominp.com.br).

Rodrigues (1998), em seu excurso sobre o pensamento pedagógico empresarial, aponta que, a partir da reestruturação produtiva, a Confederação Nacional da Indústria (CNI) busca subordinar a lógica e funcionamento do sistema educacional e de centros públicos de produção científica e tecnológica às necessidades econômicas da indústria. Com este pensamento, a CNI "competitivista" concebe a política brasileira de desenvolvimento 
tecnológico-industrial com o objetivo de garantir o crescimento quantitativo e qualitativo do setor produtivo de modo combinado à integração do mercado internacional. Para garantir a sustentabilidade de tal projeto, seria necessário que os empresários participassem de órgãos governamentais responsáveis não só pela formulação da política tecnológica, como, também, de políticas públicas de educação. Ademais, nos documentos produzidos pela entidade "fica clara a intenção de 'absorção' de tecnologias, seja explícita — isto é, através da compra de pacotes tecnológicos - , seja implícita - isto é, pela compra indireta das tecnologias embutidas nas maquinarias. Em outras palavras, o documento da CNI não propõe uma política de desenvolvimento científico voltada para a 'geração' de conhecimento (...), propõe a valorização da educação, mas uma valorização interessada, como diria Gramsci. Isto é, a Confederação pretende valorizar a educação e a ciência que atendem aos interesses do parque industrial, em particular, e aos interesses do capital, em geral; enfim, a educação que lhe convém"(p.105, grifos meus).

Assim, fundamentada, pretendo neste texto, evidenciar que a burguesia industrial, associada e dependente do capital internacional, encontra boa acolhida no Governo Lula, cujos programas de "formação e geração de renda" aprofundam as políticas neoliberais no Brasil que excluem mais que incluem. "Ao invés de defender-se do imperialismo e dos bancos, a atuação preferencial da indústria tem consistido em seguir a linha de menor resistência: atacar os direitos dos trabalhadores e apropriar-se das empresas estatais" (Boito Jr.,2002, p.66-7).

Neste contexto, Boito Jr. (2002) afirma que surge uma nova burguesia dependente diretamente da política antipopular de degradação dos serviços públicos. De posição política reacionária, a nova burguesia de serviços ocupa posição inferior em relação aos grupos industrial e bancário no bloco do poder, tendo interesse direto na política de desregulamentação do mercado de trabalho e minimização dos direitos sociais; deste modo, o crescimento do mercado nesta área ocorre a partir da venda de serviços de saúde e educação, seguros de saúde, previdência privada, etc.(Boito Jr, 2002). Dos trabalhadores de telemarketing aos motoboys, dos jovens trabalhadores nas redes de fast food aos digitalizadores do setor bancário, dos jovens vendedores em grandes magazines aos trabalhadores de redes de turismo, dos subcontratados em cooperativas aos prestadores de serviços em ONGs, forma-se um exército de trabalhadores, denominado por Antunes (2005a) de uma nova morfologia do trabalho que a sociedade capitalista contemporânea vem ampliando - "homens e mulheres terceirizados, subcontratados, part-time, que exercem trabalhos temporários, entre tantas outras formas assemelhadas de informalização do trabalho"(p.17). É, pois, a este mercado de trabalho que se refere o Ministro do Trabalho do atual governo - "as ocupações ligadas ao setor de serviços vêm tendo e devem continuar a ter desempenho bastante favorável em futuro próximo". Assim sendo, concordo inteiramente com Antunes (2005a), quando afirma assim "como o capital torna 'supérfluas' suas mercadorias, sem as quais, entretanto, não pode sobreviver, o 
mesmo capital torna 'supérflua' sua mercadoria força de trabalho, sem a qual também não pode sobreviver" (p.28).

Vale repetir, mesmo sob pena de ser redundante, que o modelo neoliberal de acumulação de capital promove a desregulamentação e desestruturação da sociedade, acarretando desemprego, trabalho temporário, baixos salários, terceirização, que, por sua vez, precarizam a existência humana. Tomando como princípios que o homem é um ser social e que a reprodução da vida, na contemporaneidade, requer dos setores populares a criação de estratégias de trabalho e sobrevivência, Tiriba (2004) salienta que a economia global não se resume apenas à economia capitalista e, embora setores populares não tenham acesso à ciência da economia, "existe um saber popular em matéria de economia" que conta com diferentes estilos de solidariedade e associatividade. Embora subalterna e dependente da economia capitalista, a economia popular conta com relações de comensalidade, doação, reciprocidade e de cooperação (p.84).

Paradoxalmente, no Governo Lula da Silva, o processo de fortalecimento de economias populares, iniciado em 2001, torna-se parte integrante das políticas do MTE com a criação da Secretaria Nacional de Economia Solidária, e é por este motivo que Luiz Marinho cita a economia solidária como uma das oportunidades que estão sendo criadas pelo Estado. A este processo integram-se vários intelectuais e educadores que "têm se dedicado à economia popular, economia solidária, cooperativismo e autogestão como uma das dimensões do mundo trabalho e da formação humana" (Picanço; Tiriba, 2004, p.23). Vários projetos de geração de trabalho e renda de caráter associativo, acompanhados de qualificação profissional, estão em fase de execução. As autoras salientam que, sendo a realidade contraditória, surgem, então, outras formas de trabalho não limitadas à reprodução do capital, mas, sobretudo, da própria vida, passando "a (re)surgir ou a se manifestar com maior intensidade". Se por um lado o sistema do capital leva às últimas conseqüências o processo de exploração da força de trabalho, inovando e precarizando as formas de apropriação, de outro, "contraditoriamente, a produtividade demandada pelo capital, ao mesmo tempo em que obriga os trabalhadores a estabelecer determinadas formas de relação entre capital e trabalho, os impele a recriar antigas e novas relações econômico-sociais e, por conseqüência, repensar o sentido mesmo da práxis produtiva"(p.25). Este é o pensamento-diretriz de intelectuais e educadores que, ao perceberem no movimento da economia solidária um novo espaço onde o trabalho seja princípio educativo, vislumbram o caminho para subverter a lógica da pedagogia empresarial capitalista.

\section{Considerações finais}

O Brasil do início do século XXI é um país que preserva marcas profundas do sistema escravocrata, ao mesmo tempo em que apresenta características de uma sociedade 
moderna industrial; é o ornitorrinco[15] — altamente urbanizado; população e força de trabalho, no campo, reduzidas, entretanto com forte agrobusiness; setor industrial taylorista-fordista completo, avançando por meio da revolução digital-molecular que associa a microeletrônica aos processos de informação automática à maquinaria; estrutura de serviços diversificada; sistema financeiro atrofiado - , por viver a democracia há três décadas, "parece dispor de 'consciência' [mas, por] faltar-lhe, ainda, produzir conhecimento, ciência e técnica: basicamente, segue copiando"(Oliveira, 2003, p.133-4).

O resultado deste processo histórico define não só o tipo de sociedade, vivida por brasileiros, constituída nos planos da estrutura econômico-social e superestrutura jurídicopolítico-ideológica na sua relação com o interno e o externo, mas, também, o estágio de desenvolvimento tecnocientífico que expressa sua posição/situação na divisão internacional do trabalho e suas implicações com as demandas do trabalho - uma sociedade dividida entre o tradicional/atrasado/subdesenvolvido e o moderno/desenvolvido; cindida em classes, fonte da expropriação do trabalho.

No Brasil, o neoliberalismo iniciado no Governo Collor de Mello, e desenvolvido no período de FHC, acarretou o desemprego, a precarização do trabalho e exclusão social. Neste período, o parque produtivo foi alterado e retraído pela política de privatização de estatais, especialmente, siderurgia, telecomunicações e energia elétrica, o que modificou o tripé que sustentava a economia brasileira - capital nacional, capital internacional e setor produtivo brasileiro - , elevando sobremodo a integração/subserviência do país ao capitalismo central.

A reestruturação produtiva se desenvolveu não só por meio da lean production, just in time, qualidade total, mas também da descentralização produtiva que levou indústrias, como as de calçados e têxtil, a se deslocarem sob a alegação de concorrência internacional. Deste modo, o Brasil integrou-se à chamada fase de mundialização ou globalização, ampliando o grau de dependência ao capital estrangeiro, adaptando-se externamente ao mundo globalizado e desintegrando-se internamente. "Diferente do que Marx previu, de modo otimista, que o crescimento da maquinaria levaria o homem ao reino da liberdade, assistimos, cada vez mais, a classe trabalhadora sendo levada ao reino da necessidade. Os novos paradigmas tecnológicos sustentam novos modos de organização do trabalho, novos mecanismos de dominação e exploração da classe trabalhadora" (Silveira, 2006, p.5).

Antunes (2005b) aponta que em 1989, no Brasil, vivenciava-se um ciclo de lutas e avanços sociais, iniciado com a fundação do Partido dos Trabalhadores (PT), da Central Única dos Trabalhadores (CUT) e do Movimento dos Sem - Terra (MST), no entanto, hoje, o quadro é bem diferente, no Governo Lula da Silva: "em vez de iniciarmos uma nova era, de desmontagem do neoliberalismo, atolamos e chafurdamos na continuidade do nefasto 
projeto de desertificação social e política do país, iniciado por Collor, desenvolvido por FHC e agora mantido pelo governo do PT"(p.155). O Governo Lula aprofunda a política iniciada por seus antecessores com o desmonte da política de previdência pública, defende a flexibilização das leis do trabalho em favor do capital internacional.

Por ser a natureza estrutural das relações sociais do sistema do capital a mesma em todos os países, isto é, os meios e instrumentos de produção e comunicação são propriedades privada dos capitalistas e, por conseguinte, a extração da mais mais-valia, absoluta e relativa ou combinada, são centrais para reprodução do capital, o desemprego afeta todos os países, sobretudo os países da América Latina, como o Brasil, e pessoas que ainda se encontram empregadas têm de suportar a degradação de suas condições materiais de reprodução da sua existência. Neste sentido, Mészáros (2003) afirma que a ascensão histórica do capital trouxe consigo "uma equalização para baixo da taxa diferencial de exploração"(p.27).

Como o metabolismo social do capital é incompatível com as relações de igualdade entre os seres humanos, e não tem a finalidade de satisfazer as necessidades humanas, para combater a precarização do emprego seria preciso elaborar uma política econômica que avançasse na superação do neoliberismo, principalmente em pontos como a eliminação da superexploração do trabalho, de modo a retirar o trabalhador do reino da necessidade.

Na maioria das respostas do Ministro do Trabalho, seja ao afirmar que "a qualificação se tornou um fator fundamental para melhor inserção e manutenção do trabalhador no mercado" seja por acreditar que o mercado vai crescer "por conta do Programa Universidade para Todos (Prouni)", fica claro que a educação tem duas funções principais em uma sociedade capitalista: por um lado, tende a reproduzir as relações de desigualdade ao oferecer qualificações específicas para o funcionamento da economia e, por outro, por não se reduzir apenas a reprodutora, a educação ocorre, não só em processos educativos formais, como, também, em outras dimensões da vida humana que interessam à classe subalterna e a seu projeto histórico de superação do modo capitalista de produção.

Finalizo este texto, refletindo sobre as perspectivas de educação frente à crise do trabalho assalariado. Observa-se, há décadas, nos discursos, que o problema do desemprego só tem solução com investimento em educação. Repetindo o discurso retórico, seja na ótica da ideologia do capital humano, seja nas teses da pedagogia das competências e empregabilidade, o Governo Lula vem implantando e implementando vários programas de formação de jovens e adultos para o trabalho, como o Programa Primeiro Emprego do MTE, Jovem Aprendiz, Escola de Fábrica, Programa Nacional de Inclusão de Jovens, etc. Não quero, aqui, menosprezar a importância de ações focalizadas, que pretendem a inserção imediata de jovens e adultos em oportunidades surgidas no mercado de trabalho, 
no entanto, não podemos nos deixar iludir. O Brasil é o país econômica e politicamente mais importante da América Latina, entretanto, o ensino médio não é obrigatório, e apenas aproximadamente $46 \%$ dos jovens[16] estão cursando este nível de ensino. A não obrigatoriedade do ensino médio indica não só a opção de formação para o trabalho simples, mas, também, o descomprometimento com a ampliação das bases de produção técnica, científica e tecnológica.

Neste sentido, torna-se fundamental retomar o debate sobre a concepção politécnica de educação na qual intelectuais da área de educação entendem o trabalho humano como categoria ontocriativa, princípio educativo mediado pela tecnologia. "A concepção de educação politécnica pressupõe uma visão social de mundo radicalmente distinta daquela que, hegemonicamente, se apresenta nas sociedades atuais" (Rodrigues, 2005, p.273). Isto significa um projeto de educação e formação profissional para a classe trabalhadora jovens e adultos - em que sejam desenvolvidos os fundamentos tecnocientíficos para o trabalho complexo.

Assim, então, teríamos uma sociedade em que desenvolvimento científico tecnológico não seria pressuposto do desemprego, mas, sim, a incorporação do trabalho morto ao processo produtivo, de modo que, livres da sociedade classista, a ciência, a técnica e a tecnologia diminuiriam o tempo de trabalho necessário, liberando tempo livre (Frigotto, 2006, p. 245).

\section{Referências bibliográficas}

ANTUNES, Ricardo. O caracol e sua concha: ensaios sobre a nova morfologia do trabalho. São Paulo: Boitempo, 2005a.

$2005 b$.

. A desertificação neoliberal no Brasil (Collor, FHC e Lula). Campinas: Autores Associados,

BOITO Jr. Armando. Política neoliberal e sindicalismo no Brasil. São Paulo, Editora Xamã, 2002.

BRASIL/MTE. Plano setorial de qualificação. Disponível:

http://www.mte.gov.br/Trabalhador/QualProf/Conteudo/Orientacoes_Plano_Setorial_de_Qualificacar

BRASIL/MTE. Levantamento preliminar do Plano Setorial de Qualificação (Planseq). Disponível: http://www.mte.gov.br/Noticias/Conteudo/11077.asp

BRASIL/IBGE. Pesquisa industrial de emprego e salário. Disponível:

http://www.ibge.gov.br/home/presidencia/noticias.

BRASIL/MME. Programa de Mobilização da Industrial Nacional de Petróleo. Disponível: http://www.prominp.com.br 
CUNHA, Luiz Antônio. Educação e desenvolvimento social no Brasil. Rio de Janeiro: Francisco Alves, 1975.

FRIGOTTO, Gaudêncio. A produtividade da escola improdutiva: um (re) exame das relações entre educação e estrutura econômico-social e capitalista. São Paulo: Cortez, 2001.

. Fundamentos científicos e técnicos da relação trabalho e educação no Brasil de hoje. In: LIMA, Júlio César França; NEVES, Lúcia Wanderley (Orgs). Fundamentos da educação escolar do Brasil contemporâneo. Rio de janeiro: FIOCRUZ, 2006.

HOBSBAWM, Eric. Era dos extremos: o breve séculoXX: 1914-1991. São Paulo: Companhia das Letras, 1995.

MÉSZÁROS, István. O século XXI: socialismo ou barbárie?. São Paulo: Boitempo, 2003.

OLIVEIRA, Francisco. Crítica à razão dualista. O Ornitorrinco. São Paulo: Boitempo, 2003.

PICANÇO, Iracy; TIRIBA, Lia. O trabalho como princípio educativo no processo de produção de uma "outra economia". In: PICANÇO, Iracy; TIRIBA, Lia (Orgs). Trabalho e educação: arquitetos, abelhas e outros tecelões da economia popular solidária. São Paulo: Idéias \& Letras, 2004.

RODRIGUES, José. O moderno príncipe industrial: o pensamento pedagógico da Confederação Nacional da Indústria. Campinas: Autores Associados, 1998.

- Ainda a educação politécnica: o novo decreto da educação profissional e a permanência da dualidade estrutural. In: Trabalho, Educação e Saúde - v.3,n.2. RJ: FIOCRUZ, EPSJV.

TIRIBA, Lia. Ciência econômica e saber popular: reivindicar o "popular" na economia e na educação. In: PICANÇO, Iracy; TIRIBA, Lia (Orgs). Trabalho e educação: arquitetos, abelhas e outros tecelões da economia popular solidária. São Paulo: Idéias \& Letras, 2004.

SILVEIRA, Zuleide S. da. Tecnologia e sociedade: a questão da não-centralidade do trabalho. (no prelo).

\section{Estudo V: \\ Fios do discurso e armadilhas da promessa: \\ Provocações de uma entrevista}

Ozias de Jesus Soares[17]

\section{Fios do discurso e armadilhas da promessa - provocações de uma entrevista}

“Ora, o 'pessimismo da razão', como nos ensinou Gramsci, não cancela o 'otimismo da vontade', sempre que sustentados no realismo da análise"[18] 
Recentemente publicada por uma jornal de grande circulação no Brasil, a entrevista do atual ministro do trabalho, Sr. Luiz Marinho, para a qual foi dado o sugestivo título "o emprego não acabou", provoca um movimento necessário de análise das práticas e discursos que se pretendem direcionados à classe trabalhadora. Na bifurcação de tudo o que aduziu o entrevistado, é possível identificar pelo menos dois caminhos que, concretamente, fundem-se num só: (1) com que pressupostos foi construído o discurso do ministro - ou seja, os fios do discurso; e (2) quais são projeções apontadas para a relação trabalho-educação na atualidade brasileira - as armadilhas da promessa.

Não pretendemos neste texto aprofundar todos os aspectos presentes na fala do entrevistado, entretanto, torna-se necessário evidenciar e, com isso, colocar sob o clivo da teoria produzida numa direção crítica, alguns pontos da referida entrevista.

\section{Entendendo o emaranhado - ou puxando alguns fios}

Numa visão rápida e geral sobre a entrevista concedida por Luiz Marinho, é possível perceber uma primeira preocupação do entrevistado. Ocupando um das pastas principais no governo de qualquer país, o Ministério do Trabalho, pressupõe-se, pela própria especificidade do que o torna necessário, ou seja, a atuação em políticas públicas voltadas para o trabalhador, um cargo que carrega consigo as contradições inerentes ao sistema capitalista que ora estamos imersos.

Considerando os fatos que marcaram profundamente a nossa história e a teia de relações subordinadas que o país ocupa na nova aldeia global, podemos dizer que, no nível do que se mostra no imediato, a complexidade e o horizonte sombrio, entre outros, desenham a inviabilidade de uma saída alternativa - senão a mudança própria na estrutura que engendra as relações de dominação, exploração e acumulação. Se a objetividade posta apresenta-se enquanto grandes barreiras à derrocada do atual sistema capitalista, é fato que o desejo de perpetuação do status quo, que compõe o "DNA" da elite-dominantenacional-casada-à-internacional mantém-se irretocável. Com isso, a preocupação (e ocupação) de um gestor do Estado, essencialmente burguês, em qualquer aparição pública, limitar-se-á - em primeira instância - com a exposição e balanço dos serviços prestados - ou prestação de contas - do que propriamente elucidar as grandes questões que circundam hoje a esfera da relação trabalho-educação em nossa sociedade. Assume, portanto, apenas um caráter partidário do que de análise das transformações e crises no/do atual mundo do trabalho. Podemos, daí, puxar um primeiro fio no emaranhado das questões postas pelos que representam os interesses do Estado: a fala estaria ligada ao esforço de prestar contas da gestão e do programa do governo.

Um segundo ponto de análise - ou fio do discurso - é a identificação que, forçosa e 
propositadamente, se faz entre o incremento da maquinaria, das novas tecnologias, com a complexificação das relações de trabalho - ou melhor, com a deterioração dessas relações. Querem parecer que se tratam da mesma moeda com duas faces.

Divulga-se à grandes letras que "o mercado de trabalho ficou mais complexo". Com isso, encerram-se baixo a esta premissa todas as formas e modalidades de trabalho e geração de renda, os "novos modelos" de contratos de trabalho, e as sutis ou abertas formas de exploração do trabalhador. Junto a isso, diz-se que o carro-chefe que provoca e conduz as "transformações" são as fantásticas máquinas e tecnologias de ponta. Se "um novo paradigma de produção industrial alternativo à produção fordista"[19], fez emergir esquemas chamados hoje de acumulação flexível e toyotismo[20], concordamos também que as alterações na esfera da produção e do trabalho são fruto das relações sociais que os homens estabelecem entre si. Concordando com Saviani (idem), diria que o criador deste processo, aquele que o domina plenamente e que o controla em última instância, continua sendo o homem. Continua, pois, sendo um trabalhador. Seu trabalho consiste agora em comandar e controlar todo o complexo das suas próprias criaturas, mantendo-as ajustadas às suas necessidades e desenvolvendo-as na medida das novas necessidades que forem se manifestando[21]

O que, num primeiro momento pode-se depreender é que as operações mentais, intelectuais e motoras que o homem precisa desenvolver face às novas ferramentas produtivas são, de fato, novas e complexas. No entanto, "as máquinas, como extensão dos braços e agora também do cérebro humano, não são mais do que instrumentos através dos quais o homem realiza aquela atividade, ainda que se trate de instrumentos capazes de pôr em movimento operações complexas, múltiplas, amplas e por tempo prolongado"[22]. Vale dizer, portanto, que a aparente complexidade, a que alude o ministro em sua fala, apenas se explica ante a necessidade do capital em viabilizar a subsunção formal e real do trabalho[23]. Não são as máquinas que trazem as transformações. São as relações e os usos sociais delas.

Sendo o mercado de trabalho dinâmico e incorporador de novas tecnologias, nadas mais justo, dizem, que este trabalhador seja também dinâmico, criativo, e aceite as mudanças trazidas (ou leia-se, impostas) pelas transformações do nosso século[24]. Dessa forma, a (con)fusão que querem parecer una a complexificação tecnológica enquanto possuidora do "gene" da complexificação das relações de produção e trabalho (leia-se o estabelecimento de novas e dilapidadas relações) ancoram-se, tão somente, no aparato ideológico da manutenção de uma sociedade cingida pela desigualdade e espoliação do trabalhador.

A marca, tanto da precedência do empresariado nacional quanto do dualismo na educação brasileira, é exposto na afirmação de Marinho com respeito ao Sistema S. Nascido como resposta da burguesia nacional ao "atraso" na educação brasileira para a urgente e necessária formação de quadros para a indústria[25], o Senai e Senac, junto ao Sesi (Serviço Social da Indústria), representaram na década de 40, e subseqüentes, o primor da 
formação profissional no Brasil. Dada a urgência da formação, aliada ao atraso econômico e social vigentes na época, a saída era oferecer bolsas de estudos como complementação de renda aos estudantes dos cursos do Senai[26]. Na proposta de requalificação de mãode-obra, o currículo do Senai era atualizado com as permanentes mudanças do chão-dafábrica. Seis décadas são transcorridas desde aquela fundação e, radicalmente, o que é visto hoje são cursos, considerados ainda de qualidade, com elevados custos para quem deles quer participar. O momento ainda é inicial para perceber de todo as linhas-mestras das mudanças no sistema S. O que se pode dizer, talvez, é que os valores cobrados pelo sistema $S$, representariam menos uma seletividade da mão-de-obra, através do filtro de "quem-pode-pagar" e "quem-não-pode-pagar" e mais o repasse dos empresários aos próprios trabalhadores nas suas demandas por formação. Seria uma desoneração do capital - contrariamente às décadas pós-1940 - com respeito à formação do trabalhador, garantindo, porém, a mesma qualidade e (con)formação através do órgão eleito como legítimo interesse do empresariado nacional.

Quando o Ministro do trabalho, na entrevista, diz que o governo conta "também com o sistema S", o entrevistador aponta as reclamações que se fazem com respeito aos preços altos dos cursos do sistema $\mathrm{S}$. Entendendo os fios do discurso, diria que a total falta de resposta e esclarecimento quanto à questão do sistema $\mathrm{S}$, em especial o Senai, no tocante aos preços dos cursos ali oferecidos, a resposta do ministro à questão do entrevistador aponta para uma certa evasiva e não enfrentamento dos problemas que se colocam hoje à formação profissional.

O monstro que a esquerda brasileira atacou desde meados da década de 80 , assenta-se na cadeira ao lado da mesa de jantar. O ministro, criado na militância sindical ao lado dos trabalhadores, convida o empresariado a somar forças na retroalimentação do capital. Trata-se de uma outra ponta deste emaranhado que começou a ser entendido há algum tempo[27] e que agora revela a sua total face. Destaca-se da fala de Marinho o exemplo emblemático da amistosa relação entre Estado e empresariado quando aborda a questão da educação como uma grande fatia de mercado, alimentada pelo Programa Universidade Para Todos (PROUNI), do governo federal. A privatização do público, como um monstro, deveria ser atacada e eliminada quando os trabalhadores chegassem ao poder. Esta era a tese. A educação deixa de ser um serviço essencialmente público, com caráter fundamentalmente de formar as novas gerações, incrementar a ciência e a tecnologia, bem como trabalhar na formação política da população, para incorporar-se ao chamado "mercado". Esta é a prática. O ministro aconselha que os jovens busquem na educação uma possibilidade de inserção profissional pois, segundo ele este "mercado" vai crescer. Em sua fala, aponta que "vale a pena investir no setor de serviços, na área da educação". Isto, para ele, se deve fundamentalmente às milhares de vagas surgidas nas instituições privadas de ensino superior. Vejamos:

Entrevistador: No caso da educação, por que o mercado vai crescer? MARINHO: O número de estudantes de curso superior deve crescer por conta do 
Programa Universidade para Todos, o PROUNI, do governo federal, que, no primeiro processo seletivo, ofereceu 112 mil bolsas integrais e parciais, em 1.142 instituições de ensino superior do país, e, em 2006, oferecerá 130 mil bolsas.

O embate em torno da oferta de educação escolar marcou as páginas da história do Brasil. Em meados do século XVIII, o Estado colonial põe fim ao ensino jesuítico instaurando uma trajetória de lutas em torno da composição laica ou religiosa do ensino que, guardadas as devidas proporções, estende-se até os nossos dias. Com a República o debate reacendese, todavia, prevalecendo o interesse de um Estado que se pretendia laico, livre de injunções da igreja. No entanto, este mesmo Estado que reivindicava a laicidade do ensino foi moroso em instalar uma educação pública e de qualidade à toda a população. Os interesses das classes dominantes trazem para o cenário um aprofundamento das desigualdades que moldaram a própria formação da sociedade brasileira: a iniciativa privada tratou de mostrar que o ensino que se praticava dentro de seus muros seria sempre superior ao do Estado. Forçoso é dizer que a maioria das escolas que mantiveram desde lá esta qualidade do ensino era/é vinculada à Igreja[28]. Sublinhamos, porém, nesta nossa análise do emaranhado de fios, que o Estado ora financiava diretamente bolsas de estudos na iniciativa privada, ora concedia incentivos fiscais às instituições de ensino que declarassem seus certificados de filantropia ${ }^{[29]}$. Se falamos da formação de um Estado brasileiro sob a tutela e marca da burguesia, não é de se admirar que a perpetuação de um modelo que, sob a alegação de sanar as deficiências nas matrículas do ensino superior, mesmo com um governo dito popular e representante dos interesses dos trabalhadores, mantenha os históricos interesses da classe dirigente.

Por fim, a ligação entre o fio e a armadilha da promessa encontra-se no binômio qualificação-emprego. Luiz Marinho assegura que "a qualificação se tornou um fator fundamental para a melhor inserção e manutenção do trabalhador no mercado [...] O maior desafio do ministério hoje é elevar a escolaridade e, depois, qualificar o trabalhador." Uma primeira questão que se coloca a partir desta fala é saber o lugar da escola e da formação profissional numa sociedade com contornos fortes de uma estrutura social perpassada pelos mecanismos de exclusão e profundas desigualdades.

A corrida em busca da profissionalização e qualificação era uma tônica na burguesia nacional desde o início do século XX. A forte onda migratória trouxe ao Brasil um quantitativo grande de trabalhadores europeus, seja por conta do fim da escravidão ou por conta de uma demanda de mão-de-obra tecnicamente preparada que deixava a nascente burguesia industrial à mercê desses trabalhadores. Soma-se a isto uma extrema dependência da iniciativa, investimentos e capital estrangeiros, em especial da Inglaterra e Estados Unidos naquele momento ${ }^{[30]}$. Com a proposta do desenvolvimentismo cometidos a partir da década de 1930 e com a crise mundial que afetava os países centrais nesta época, o desafio do Estado brasileiro de então, era elevar a escolaridade dos trabalhadores e, em especial, fomentar a formação/qualificação profissional. Esta era a tônica em que se debateu os industriais na década de 30 e que motivou a modernização 
das relações capitalistas, com a clara aliança Estado e empresariado, esse último representado pela CNI (Confederação Nacional da Indústria) ${ }^{[31]}$. Era preciso qualificar, então, o trabalhador para os postos de trabalho e funções postas pela nova ordem industrial. O país, essencialmente agrário, recém egresso de uma época áurea de exportação do café, passa a incorporar em massa os trabalhadores na urbe e na fábrica. Seguiu-se aí uma tese que pretendia equacionar o problema gerado pelas contradições do sistema. A teoria do capital humano procurava explicar que o aumento da escolaridade e da qualificação do trabalhador traria, inequivocamente, o desenvolvimento nacional e o aumento da renda dos trabalhadores. Entende esta corrente que o desemprego e a precariedade dos jovens advêm da falta de adequação entre formação e emprego.

As teses da Teoria do Capital Humano, dissociada de outros determinantes ao crescimento e inserção do trabalhador no mundo do trabalho e nas práticas sociais, conforme discutiu Frigotto[32], tornava-se, na verdade, no contexto brasileiro, um artifício ideológico às classes populares. O que faz o Ministro do trabalho é reforçar tal tese e a posição do país na arena mundial da divisão internacional do trabalho ao relacionar diretamente educação/qualificação à manutenção ou garantia de emprego.

\section{Armadilhas e promessas do discurso: um novo perfil do mundo do trabalho (?)}

A passagem dos fios do emaranhado do discurso, perdido entre as contradições do capital, associam-se, diria, "simbioticamente", às armadilhas por ele produzidas. A fala do Sr.

Ministro corrobora com a idéia amplamente corrente na elite brasileira de que o mercado (o capital) para manter-se na atual conjuntura precisa minar o terreno dos direitos conquistados pela classe trabalhadora ao longo dos séculos XIX e XX[33]. Essas mesmas garantias dos trabalhadores, são relegadas a um plano secundário ao se enfocar as "novas ações de empreendedorismo", deixando claro, tanto a contradição quanto a incoerência do discurso, quando ao final exalta os números de empregos assalariados gerados com "carteira de trabalho" pelo governo federal. O que de fato quer o Ministério do Trabalho?

As novas formas de ocupação listadas por Luiz Marinho dentre as que englobam as ações de "empreendedorismo", como "os pequenos negócios" e "a economia solidária" como novas opções de trabalho, "a indústria de artesanato", situam-se longe do que alguns autores, dentre estes Tiriba[34], discutem enquanto a produção associada que representa um viés possível de contraposição ao modelo de acumulação. Antes, diria que as tais ações se inserem na necessidade da existência de uma periferia do capital, do escoamento de excedentes, e da funcionalidade harmônica do capital num momento em que bate às portas deste a sua própria desintegração pelo desemprego em massa e o conseqüente caos social. Conforme Tiriba, "as formas de geração de trabalho e renda são antes de tudo, a manifestação dos mecanismos de ajuste estrutural e do agravamento das contradições sociais"[35]. O "canto da sereia" aí seria a proposição dúbia de geração de 
empregos através das novas "ações de empreendedorismo", ao mesmo tempo que exalta a criação de empregos assalariados, devendo, para isso, especialmente os jovens, se qualificar melhor "para obtenção e manutenção de postos de melhor qualidade".

Na mesma entrevista, Marinho tangencia uma outra questão de fundamental importância no entendimento da relação capital-trabalho. A divisão internacional do trabalho, há muito, impõe uma hierarquização aos países da periferia que, quebrar esta rigidez definida pelos países centrais, torna-se tarefa difícil. A separação entre concepção e execução, produtores de tecnologia e fornecedores de matéria-prima e mão-de-obra permanece sendo a equação do sucesso do capital mundial. Curioso, no entanto, é perceber que a fala do Ministro parece apontar para a sedimentação desta divisão: alguém projeta um navio num computador; outro constrói o navio; alguém cria o programa do computador, e opera complexas operações de venda virtual; e ao outro cabe entregar o livro comprado pela internet! Estaríamos nós - brasileiros - fadados a nos tornar "entregadores de livros"? A armadilha do ministro aí é o fato de mostrar que "o avanço da tecnologia não elimina o emprego"; entretanto, se não elimina, redistribui ou reforça o escalonamento entre produtores de tecnologias e o chão da fábrica. Ou o entregador de livros. Extasiados com a tecnologia, e destinados a uma posição subalterna na cadeia produtiva.

Uma outra face do alçapão do ministro é a previsibilidade do emprego. Segundo o Luiz Marinho, "ainda teremos emprego pelos próximos 50 anos, pelo menos". Na verdade esta previsibilidade choca-se frontalmente com a perspectiva de base socialista no qual durante anos ancorou-se o Partido dos Trabalhadores, plataforma do Ministro. Para além da manutenção dos postos de trabalho na grande indústria e a luta por melhores condições de trabalho, a vinculação ideológica do Partido tinha como o horizonte, ao menos nos discursos dos seus principais militantes, um projeto societário de base socialista. A idéia da previsibilidade do emprego, tal qual alude o Ministro e dentro da conjuntura ao qual se refere, representa a própria manutenção - pelo prazo estipulado - do próprio sistema capitalista que o sustenta. Coloca-se, portanto, a perda de um horizonte assentado menos sobre o trabalho concreto e mais sobre o trabalho abstrato, o qual representa o próprio sentido do capital e a dinâmica das relações que regem os trabalhadores na atualidade. A orientação dada pelo chefe da pasta do Trabalho quanto às áreas nas quais devem investir o jovem, reacende o debate em torno da homogeneização da juventude, da inexistência das classes sociais distintas que, por sua vez, produz inserções variadas (e caracteristicamente desiguais) no âmbito da educação e formação profissional. O ministro sugere que o "setor de serviços" (hoje concretamente amplo, difuso e de difícil delimitação), especificamente na "área da educação", e "em profissões como mecatrônica" devem ser os alvos preferenciais do jovem. Segundo Luiz Marinho, não conhece "ninguém formado que esteja desempregado".

As desigualdades abissais entre as classes sociais no Brasil, como é sabido, provoca diferentes modos de inserção, de desejos e aspirações quanto ao mundo do trabalho. No 
Rio de Janeiro, como mostram dados do INEP, em 2005, cerca de 172 mil alunos da rede estadual abandonaram a escola - numa relação de 852 alunos por dia ${ }^{[36]}$. Os dados de evasão no ensino fundamental situam-se acima de $10 \%$ e na educação de jovens e adultos este índice ultrapassa os $20 \%$. E é entre os jovens da classe trabalhadora, que precisam aliar estudo e trabalho, que se situam as maiores taxas de desistência: $68 \%$ das desistências são de alunos que estudam à noite ${ }^{[37]}$. Neste contexto, o Estado brasileiro, ciente dos disparates arraigados na nossa estrutura social e na própria produção do fenômeno da exclusão e segregação social (tão caros ao capital) lança programas relâmpagos de educação e formação profissional. O mais jovem dos programas chama-se Projovem, para pessoas acima de 18 anos aos 24 anos. A idéia é oferecer o ensino fundamental aliado a uma ocupação profissional básica. Uma outra iniciativa foi batizada também pelo Governo Federal de "Escola de fábrica", onde ao jovem de 16 a 24 anos será dada uma "profissão", recebendo uma bolsa-auxílio de $\mathrm{R} \$ 150,00$ e o aprendizado será dado na própria empresa conveniada com o Governo[38]. As ocupações desses jovens e desses programas situam-se num patamar de inserção imediata e subalternizada no mercado de trabalho. Estes não farão Educação ou Mecatrônica. E são maioria. O que farão/serão? Investir cinco anos em formação profissional, para tentar ingressar logo após no mercado de trabalho, é garantia de emprego? A dinâmica acelerada do mundo da produção de das atuais relações de trabalho permitem planejamentos a médio e longo prazo para os jovens? Qual é a questão central posta pelo mundo do trabalho atual? O que o ministro chama de "estágio mais avançado de desenvolvimento" como sendo o momento de maior propulsão do setor de serviços, na verdade, aliaria a hierarquização de países/regiões com a globalização da economia somado com a incorporação de altas tecnologias na indústria, deixando para aquele setor a maior fatia de absorção da mão de obra dos trabalhadores dos países da periferia do capital.

Por fim, a preocupação com as cifras de programas de governo turva/embaça as verdadeiras contradições internas de um sistema produtor de profundas desigualdades; não se leva em consideração que os ganhos dos trabalhadores é visivelmente decrescente, os salários - em especial os criados com registro em CTPS - situam-se no patamar mínimo da sobrevivência; e o conteúdo do trabalho, as relações de trabalho continuam na matriz de alienação, exploração e acumulação. Dizer que "em 36 meses, o governo Lula gerou 3,4 milhões novos empregos com carteira de trabalho" não esconde a questão central gerada pelo capital na sua incansável busca pela acumulação e produção das desigualdades.

Assim, o que nos remete a entrevista do Sr. Luiz Marinho é a sensação da capitulação das ideologias socialistas, na direção da ampliação dos direitos conquistados pelos trabalhadores, ante a assunção do poder político estatal. Segundo Oliveira, os militantes de esquerda ao chegarem ao poder constituem-se em uma "nova classe social", na medida em que não podem ser considerados trabalhadores, e nem podem ser caracterizados como capitalistas, antes funcionam como gestores de fundos públicos, na 
direção - lamentavelmente - da manutenção do capital[39]. Mais ainda: a ausência da perspectiva da transformação nas bases em que se assenta a sociedade capitalista, bem como não entendimento da práxis humana, leva o executivo do Estado brasileiro a desconsiderar a direção hegemônica da elite dominante, e, ao curvar-se diante de suas exigências, anula/reduz a possibilidade da luta contra-hegemônica necessária à derrubada das atuais relações sociais.

Passou longe, no discurso de prestação de contas de Luiz Marinho, a perspectiva de uma educação politécnica ${ }^{[40]}$, de uma formação integral das novas gerações que alie estudo e trabalho ${ }^{[41]}$ e que caminhe para a instauração de um novo modelo de relações de trabalho não mais calcado na subordinação estreita ao capital ${ }^{[42]}$. No âmbito da relação trabalhoeducação, o ministro apenas apontou o sistema S e as "perspectivas de mercado" para os próximos anos nas quais deverão os jovens "investir". Não chegou a tangenciar qualquer crítica aos modelos atuais de educação que continuam a povoar o território da desigualdade social. Talvez o emaranhado em que se encontra seja denso demais para perceber as clarividentes contradições deste nosso sistema. Talvez não seja verdade, no entanto, que o ministro não perceba as sutis e as patentes armadilhas postas pela configuração atual do mundo do trabalho. É preciso realismo na análise.

Entre os fios do discurso do Ex.mo Sr. Ministro e as armadilhas postas ao trabalhador pelas promessas de um futuro incerto e/ou subalternizado, ficamos com uma questão: não o tempo de duração do "emprego", mas, por quanto tempo ficará a classe trabalhadora desmobilizada e fragilizada diante de vazios discursos e promessas retóricas dos "redentores" de plantão?

\section{Consultas e referências bibliográficas}

ANTUNES, Ricardo. Adeus ao trabalho? Ensaio sobre as metamorfoses e a centralidade do mundo do trabalho. São Paulo: Cortez, 1995.

CUNHA, Luiz Antonio; Góes, Moacyr. O golpe na educação. Rio de Janeiro: Jorge Zahar, 2002.

DELUIZ, Neise. Formação do Trabalhador em contexto de mudança tecnológica. In: Boletim Técnico do SENAC. Rio de Janeiro, v. 20, n. 1, 1994.

ENGUITA, Mariano F. A face oculta da escola: educação e trabalho no capitalismo. Porto alegre: Artes Médicas, 1989.

FRIGOTTO, Gaudêncio. A produtividade da escola improdutiva: um (re)exame das relações entre educação e estrutura econômico-social capitalista. (3 $3^{\underline{a}}$ ed.). São Paulo: Cortez/Autores Associados, 1989.

Fazendo pelas mãos a cabeça do trabalhador: o trabalho como elemento pedagógico na formação profissional. Cadernos de Pesquisa. n.47, nov. 1983.

Brasil: entre o medo e a esperança. In: Trabalho Necessário - Revista eletrônica do NEDDATE, Niterói, UFF, 2005. <www.uff.br/trabalhonecessario>. 
GOMES, Carlos Minayo [et al.]. Trabalho e conhecimento: dilemas na educação do trabalhador. São Paulo: Cortez, 1987.

GRAMSCI, Antonio. Cadernos do Cárcere. Volume 4 (americanismo e fordismo). Rio de Janeiro: Civilização Brasileira, 2001.

HARVEY, David. Condição pós-moderna: Uma pesquisa sobre as origens da mudança cultural. (5ํㅡㄹ ed.). São Paulo: Loyola, 1993.

HIRATA, Helena. Da polarização das qualificações ao modelo de competência. In: Ferretti, Celso et. al. Novas tecnologias, trabalho e educação: um debate multidisciplinar. 2.ed. Petrópolis: Vozes, 1994.

LEONARDI, Vitor e HARDMAN, Foot. História da Indústria e do Trabalho no Brasil. São Paulo: Ática, 1991. LISBOA, Armando de Melo. Terceiro Setor. In.: A. Cattani. A outra economia. Porto Alegre: Veraz, 2003. MARX, Karl. Para crítica da economia política. São Paulo: Abril Cultural, 1982. (Os pensadores). MARX, Karl; ENGELS, Friederich. A ideologia Alemã. São Paulo: Martins Fontes, 1998.

MONTAÑO, Carlos. Terceiro setor e questão social: crítica ao padrão emergente de intervenção social, São Paulo, Cortez, 2005.

NOGUEIRA, Maria Alice. Educação, saber, produção em Marx e Engels. São Paulo, Cortez, 1993.

NOSELLA, Paolo. A escola de Gramsci. Porto Alegre: Artes Médicas, 1992.

OLIVEIRA, Francisco de. Os direitos do antivalor. Petrópolis: Vozes, 1997.

Crítica à razão dualista/O ornitorrinco. São Paulo: Boitempo, 2003.

PROJOVEM. Programa Nacional de Inclusão de Jovens. Secretaria-Geral da Presidência da República. Coordenação Nacional do ProJOvem. março de 2005.

RODRIGUES, José. O moderno príncipe industrial: o pensamento pedagógico da Confederação Nacional da Indústria. Campinas: Autores Associados, 1998.

Educação Politécnica no Brasil. Niterói: EdUff, 1998b.

ROMANELLI, Otaíza de Oliveira. História da Educação Brasileira: 1930 - 1973. Petrópolis: Vozes, 1978. RUMMERT, Sonia Maria. Aspirações, interesses e identidade dos trabalhadores - elementos essenciais à construção da hegemonia. In: Trabalho Necessário - Revista eletrônica do NEDDATE, Niterói, UFF, 2005. $<$ www.uff.br/trabalhonecessario>

RUMMERT, Sonia Maria. Educação e identidade dos trabalhadores: as concepções do capital e do trabalho. São Paulo/Niterói: Xamã/Intertexto, 2000.

SAVIANI, Dermeval. O trabalho como princípio educativo frente às novas tecnologias. In.: FERRETTI, Celso et. al. Novas tecnologias, trabalho e educação: um debate multidisciplinar. 2.ed. Petrópolis: Vozes, 1994. SENNETT, Richard. A corrosão do caráter. conseqüências pessoais do trabalho no novo capitalismo. (4⿳亠丷a ed.). Rio de Janeiro: Record, 2000.

TIRIBA, Lia. Economia Popular e Cultura do Trabalho: Pedagogia(s) da produção associada. ljuí: Editora UNIJUÍ, 2001. 
TIRIBA, Lia; PICANÇO, Iracy. Trabalho e Educação: arquitetos, abelhas e outros tecelões da economia popular solidária. Aparecida (São Paulo): Idéias e Letras, 2004.

\section{Anexo: \\ O emprego não acabou: entrevista de Luiz Marinho a Léa Cristina}

\section{Jornal O Globo - 'O emprego não acabou’}

Data : Segunda-feira, 6 de março de 2006

\section{'O emprego não acabou'}

,O mercado de trabalho ficou mais complexo, mas não mudou tanto quanto dizem analistas, avalia o ministro do Trabalho, Luiz Marinho. O ex-presidente da Central Única dos Trabalhadores (CUT) discorda da afirmação de que o emprego tradicional, o da carteira assinada, acabou. Mas lista o empreendedorismo, os pequenos negócios e a economia solidária como novas opções de trabalho. E acaba fixando um tempo de duração para o mercado formal: "50 anos, pelo menos". Para quem está empregado, Marinho faz um alerta: não se pode mais parar de estudar. E, para os jovens, cita os setores de serviços e de alta tecnologia, inclusive no nível técnico, como os mais promissores.

Léa Cristina

\section{O emprego acabou, como dizem alguns consultores? A saída é o empreendedorismo?}

LUIZ MARINHO: Tem gente que diz muita bobagem. Um navio não é produzido por computador. Um livro comprado pela internet não chega sozinho na casa do comprador: alguém tem que entregar. $O$ avanço da tecnologia não elimina o emprego. Temos muitas ações de empreendedorismo, os novos e pequenos negócios, a economia solidária, a indústria de artesanato... todas essas são oportunidades que estão sendo criadas.

\section{Mas é essa a linha desses consultores: que o trabalhador precisa se reinventar...}

MARINHO: Sim e não. Não aceito a lógica de que o emprego tradicional acabou. Nós temos que olhar o mercado como um todo. Ainda teremos emprego pelos próximos 50 anos, pelo menos. O mercado não mudou totalmente; ele hoje é mais complexo. Tanto que há setores em que falta mão-de-obra.

Há setores, aliás, importando mão-de-obra. Para o senhor, vale a tese de que o profissional não pode mais parar de estudar?

MARINHO: A qualificação se tornou um fator fundamental para a melhor inserção e manutenção do trabalhador no mercado, assim como para obtenção e manutenção dos postos de melhor qualidade. Reconheço que temos um grande problema de mão-de-obra qualificada. Mas estamos atentos a isso. A quantidade de pessoas atendidas pelos programas do governo ainda é insuficiente. O maior desafio do ministério hoje é elevar a escolaridade e, depois, qualificar o trabalhador.

\section{O que precisa ser feito?}

MARINHO: Precisamos de um processo contínuo de qualificação, de formação: acadêmica e técnica. E esse é um desafio de governo, não só do Ministério do Trabalho. Precisamos recuperar as escolas técnicas. É preciso investir na formação de base, como o MEC está fazendo. E, com ajuda de convênios com prefeituras e entidades setoriais, investimos em unidades de qualificação nos setores aéreos e de metalurgia. Agora, faremos no setor naval, no Rio. Quanto à requalificação, contamos também com o sistema S.

Muita gente reclama dos preços dos cursos do sistema S: dizem que estão altos demais...

MARINHO: Vira e mexe temos essa reclamação, sim. Mas essa é uma discussão ainda a ser feita. De 
qualquer forma, é bom lembrar que o sistema S presta um grande serviço.

Quantos empregos devem ser criados este ano? Segundo analistas, serão mais do que em 2005, mas menos do que em 2004.

MARINHO: A geração de novos postos de trabalho deve ficar próxima à de 2004, quando, considerado o saldo entre admissões e demissões, foi gerado um milhão e meio de empregos. Estes analistas aos quais você se refere estão prevendo alta do PIB de 3\% a 3,5\% em 2006, mas acho que podemos ultrapassar este patamar.

\section{Que setores deverão empregar mais?}

MARINHO: (1) A produção industrial de bens de consumo duráveis será favorecida pela redução da taxa de juros Selic, associada ao aumento da demanda de produtos como TV em cores, por conta da Copa do Mundo, além da expressiva expansão do crédito. (2) No setor de serviços, a produção de bens voltada para a população de baixa renda ganhará escala com o reajuste do salário-mínimo de 2006. (3) A construção civil também deve abrir mais vagas por conta das melhoras no financiamento, associadas ao recente pacote de desoneração tributária dos materiais de construção. (4) Por último, para a agropecuária também temos boas expectativas: o setor deve ter um desempenho melhor do que no ano passado, quando foi bem afetado pela estiagem, por conta de medidas como o refinanciamento com recursos do FAT (Fundo de Amparo ao Trabalhador).

\section{E em que setores devem apostar os jovens que estão escolhendo uma profissão agora, para chegar} ao mercado de trabalho dentro de três a cinco anos?

MARINHO: Vale a pena investir no setor de serviços, na área da educação; e na indústria... em profissões como mecatrônica, por exemplo, não conheço ninguém formado que esteja desempregado. Setores de alta tecnologia também são recomendáveis diante da escassez de mão-de-obra qualificada. Entre as profissões técnicas de nível médio, os destaques ficam com as áreas de ciências físicas, químicas e engenharia; técnicos em ciências administrativas e em ciências biológicas e bioquímicas.

\section{Como o senhor analisa o mercado de trabalho brasileiro hoje?}

MARINHO: Tradicionalmente, na medida em que as economias se desenvolvem, num primeiro estágio principalmente, a parcela dos empregos no setor industrial aumenta, enquanto a importância relativa do emprego agrícola diminui. Em um estágio mais avançando de desenvolvimento, o setor mais dinâmico em termos de geração de empregos passa a ser o de serviços. No Brasil, na década de 90, observou-se crescimento da importância relativa dos serviços no total de empregos. Tal fato se explica, também, pelo fraco desempenho da produção industrial do começo da década de 90 até 2003. Assim, as ocupações ligadas ao setor de serviços vêm tendo e devem continuar a ter desempenho bastante favorável em um futuro próximo.

\section{No caso da educação, por que o mercado vai crescer?}

MARINHO: O número de estudantes de curso superior deve crescer por conta do Programa Universidade para Todos, o PROUNI, do governo federal, que, no primeiro processo seletivo, ofereceu 112 mil bolsas integrais e parciais, em 1.142 instituições de ensino superior do país, e, em 2006, oferecerá 130 mil bolsas.

\section{O Estado do Rio deve continuar na terceira posição entre os que mais empregam? Em que setores a} oferta de trabalho tende a aumentar?

MARINHO: Em 2006, em termos absolutos, o Rio deverá continuar em destaque como um dos estados que mais gera empregos formais no Brasil. As explicações para isso são o próprio tamanho do mercado, mas, especialmente, os pesados investimentos que o presidente Lula está fazendo na região - como na construção da Vila Pan-Americana, com recursos do FAT; a recuperação da indústria naval a partir da construção das plataformas etc.

O presidente Lula esperava criar dez milhões de empregos em quatro anos. As estimativas hoje são de que essas vagas ficarão pela metade, em cinco milhões. A que o senhor atribui a diferença? Promessa de campanha, crescimento contido ou simples erro de projeção? 
MARINHO: O programa de governo do presidente Lula constatou a necessidade de gerar dez milhões de novos postos de trabalho. A promessa de campanha do presidente foi trabalhar fortemente para gerar o maior número de empregos possíveis. E este compromisso está sendo cumprido. Em 36 meses, o governo Lula gerou 3,4 milhões novos empregos com carteira de trabalho. Quando falamos em cinco milhões, estamos nos referindo só a empregos com carteira assinada. Não consideramos sequer os postos de trabalho criados via investimentos pesados que este governo está fazendo na agricultura familiar nem tampouco os criados na economia solidária. Considerando todos os tipos de ocupações, o governo pode gerar algo em torno de 8 a 8,5 milhões de postos de trabalhos.

http://oglobo.globo.com/jornal/suplementos/boachance/192099367.asp

[1] Datada de 22 de junho de 2002, alguém a apelidou de "carta ao povo brasileiro dono de banco". Disponível em <www.iidg.nl/collectiond/carta_ao_povo_brasileiro.pdf>. Acesso em 14 de agosto de 2006.

[2] Cientista Social, mestranda em educação (UFF), bolsista CAPES. jbarros almeida@yahoo.com.br

[3] É salutar a informação de que este é um ex-diretor da central única dos trabalhadores (CUT) que durante a década de 80 rompe com outras centrais sindicais diante da impossibilidade de autonomia e independência política, com o objetivo de criar uma entidade que de fato representasse os trabalhadores.

[4] Compreendemos aqui o desemprego estrutural como imanente ao sistema capitalista, ou seja, é um desemprego necessário para a manutenção da acumulação capitalista. É uma forma de descartar mão-deobra que se mostra desnecessária, impossível de ser assimilada pelo sistema. Logo é uma falácia o discurso de que é possível o pleno emprego na totalidade da sociedade, uma vez que a partir da necessidade de reestruturação do sistema capitalista houve uma diminuição arrasadora da necessidade de se incorpora o trabalho vivo a produção. Este por sua vez, impossível de ser eliminado. Para melhor compreensão destas questões ler : A Condição pós-moderna do David Harvey e o Sexto Capítulo Inédito do Capital, de Karl Marx.

[5] "...a idéia de Capital Humano é uma quantidade ou grau de educação e de qualificação, tomando como indicativo de um determinado volume de conhecimento, habilidades e atitudes adquiridas, que funcionaram como potencializadores da capacidade de trabalho e produção. Desta suposição deriva-se que o investimento em capital humano é um dos mais rentáveis, tanto no plano geral do desenvolvimento das nações, quanto no plano da mobilidade individual." ( Frigotto, 1999, p.41)

[6] Pedagoga, mestranda em Educação (UFF), professora substituta da UERJ na Faculdade de Educação da Baixada Fluminense. moniribeiro25@yahoo.com.br

[7] A Constituição Federal prevê, em seu artigo 149, três tipos de contribuições que podem ser instituídas exclusivamente pela União: (i) contribuições sociais, (ii) contribuição de intervenção no domínio econômico e (iii) contribuição de interesse das categorias profissionais ou econômicas. Essa última hipótese de incidência é que fornece o fulcro legal para a exigência de um conjunto de onze contribuições que, por motivos óbvios, convencionou-se chamar de Sistema S.

[8] Termo utilizado para designar as novas mudanças sócio-políticas e econômicas no final do século XX, ligadas ao neoliberalismo e a globalização.

[9] O critério para distribuição das bolsas é a renda familiar. Recebem bolsas integrais estudantes que possuam renda familiar, por pessoa, até um salário mínimo e meio. A bolsa parcial pode ser de $50 \%$ ou $25 \%$. Recebem bolsa de $50 \%$ estudantes que possuam renda familiar, por pessoa, até três salários mínimos. A bolsa de $25 \%$ é concedida a estudantes que possuam renda familiar, por pessoa, de até três salários mínimos, concedidas somente para os cursos com mensalidades até $R \$: 200,00$.

[10] Nota de corte é o valor que as instituições dão aos cursos. Por exemplo, só entram no curso de medicina os alunos que conseguirem a nota de corte dez no ENEM.

${ }^{1}$ Supervisora Educacional da Rede Municipal de Educação de Niterói (SME/FME), atuando na E.M. Paulo 
Freire, mestranda em educação. cris03072002@yahoo.com.br.

[12] Ver TAVARES, Maria Augusta. Os fios (in)visíveis da produção.São Paulo: Cortez, 2003.

[13] Professora do CEFET/RJ, mestranda em educação (UFF). zuleidesilveira@terra.com.br; zuleide@cefetrj.br.

[14] Segundo o Dieese, devido ao "comportamento típico de um mercado de trabalho pouco estruturado, com grande disponibilidade de mão-de-obra e dinamizado por uma estrutura produtiva marcada por grandes diferenças entre as empresas (tamanho, tecnologia, participação no mercado, etc.)" foi necessário estabelecer alguns conceitos para que fosse realizada a Pesquisa de Emprego e Desemprego (PED):"desemprego aberto: pessoas que procuraram trabalho de maneira efetiva nos 30 dias anteriores ao da entrevista e não exerceram nenhum trabalho nos sete últimos dias; desemprego oculto pelo trabalho precário: pessoas que realizam trabalhos precários - algum trabalho remunerado ocasional de autoocupação - ou pessoas que realizam trabalho não-remunerado em ajuda a negócios de parentes e que procuraram mudar de trabalho nos 30 dias anteriores ao da entrevista ou que, não tendo procurado neste período, o fizeram sem êxito até 12 meses atrás; desemprego oculto pelo desalento: pessoas que não possuem trabalho e nem procuraram nos últimos 30 dias anteriores ao da entrevista, por desestímulos do mercado de trabalho ou por circunstâncias fortuitas, mas apresentaram procura efetiva de trabalho nos últimos 12 meses ( http://www.dieese.org.br/ped/pedmet.xml).

[15] O ornitorrinco é carnívoro, alimenta-se de insetos, vermes e crustáceos de água doce, tem o corpo adaptado para uma vida aquática ou terrestre. Apesar de ser mamífero, o ornitorrinco põe ovos que são parcialmente chocados no interior do corpo. Diferente de outros mamíferos placentários, as fêmeas deste animal não têm mamilos e seus filhotes sugam o leite materno dos poros existentes na barriga da mãe. $O$ ornitorrinco representa um ramo de mamíferos que se diversificou no cretáceo inferior, mas não está classificado com os mamíferos placentários. É este animal, nem réptil e nem mamífero - um animal improvável na escala da evolução -, que Francisco Oliveira usa como metáfora para qualificar a espécie de capitalismo engendrado na sociedade brasileira que articula moderno e atraso, cidade e campo, urbano e rural, indústria e agricultura, sociedade esta que vive do processo de simbiose entre moderno e arcaico.

[16] Segundo a Comissão Especial de Políticas Públicas para a Juventude, o relatório 2003 do Fundo de População da Organização das Nações Unidas (ONU) aponta dados que o Brasil é o quinto país do mundo com maior percentual de jovens em sua população. São 51 milhões entre 10 e 24 anos $(30 \%$ do total de habitantes), sendo que 8 milhões de adolescentes têm baixa escolaridade e 3,3 milhões de adolescentes não freqüentam a escola.

[17] Técnico em Educação do Ministério da Cultura (lotado no Instituto do Patrimônio Histórico e Artístico Nacional), mestre em educação (UFF).

[18] Carlos Montaño, Terceiro Setor e questão social - crítica ao padrão emergente de intervenção social, São Paulo, Cortez, 2005.

[19] Helena Hirata, 1994.

[20] David Harvey, 1993.

[21] Dermeval Saviani, 1994.

[22] Idem.

[23] O que Marx chama de subsunção formal era definido como a extração da mais-valia absoluta através do sobretrabalho; neste caso, o trabalhador foi "convertido de trabalhador independente para trabalhador assalariado /.../ arrancado da esfera doméstica e destituído dos meios de produção" (Enguita, 1989:15) e, com isso, o capitalista passa a "supervisionar diretamente a intensidade do processo de trabalho ou prolongar a jornada de trabalho" (idem). A subsunção real era, então, a ampliação da mais-valia através do uso da maquinaria; aí, o trabalhador perde o total controle sobre o processo de trabalho, agora 
organizado eficazmente pelo capitalista, incrementado pelo uso da maquinaria. Ocorre, daí, uma superexploração do trabalho e a extração do que Marx chamou de mais-valia relativa, podendo até haver redução da jornada de trabalho, no entanto, permanecer ou aumentar a produção. No entanto, abre-se a possibilidade - o que é mais comum - do capitalista extrair a mais-valia absoluta e também relativa.

[24] Richard Sennet (2002).

[25] José Rodrigues (1998).

[26] Luiz Antonio Cunha e Moacyr de Góes (2002).

[27] Para um entendimento da cooptação da esquerda brasileira, e a funcional aliança à manutenção dos interesses hegemônicos do capital, ver Francisco Oliveira, o Ornitorrinco , 2003.

[28] Sobre este tema ver Otaíza de Oliveira Romanelli (1978).

[29] Idem.

[30] Ver Hardman e Leonardi, História da Indústria e do Trabalho no Brasil, 1993.

[31] José Rodrigues, o moderno príncipe industrial, 1998.

[32] Gaudêncio Frigotto, A produtividade da escola improdutiva, 1989.

[33] Frigotto, em recente texto sobre a conjuntura nacional aborda esta questão quando faz um balanço das propostas de governo do presidente Lula. Coloca que desde 20020 governo assinou uma carta compromisso com o Fundo Monetário Internacional (2005).

[34] Sobre este tema conferir o livro de Lia Tiriba, "Economia Popular e Cultura do trabalho - pedagogia(s) da produção associada", 2001.

[35] Idem, p. 370.

[36] Conforme mostra a reportagem do Jornal Extra de 02 de abril de 2006.

[37] Conforme reportagem no Jornal Extra de 03 de abril de 2006.

[38] Informações do endereço www.mec.gov.br/setec/escoladefabrica .

[39] Francisco Oliveira, O ornitorrinco, 2003.

[40] Rodrigues, José. Educação Politécnica no Brasil, 1998b.

[41] Sobre este tema, é fundamental a leitura do livro "Educação, saber, produção em Marx e Engels", de Maria Alice Nogueira, 1993.

[42] Sonia Rummert discute as propostas de educação da CUT (Central Única dos Trabalhadores, da qual foi presidente o atual Ministro do Trabalho), onde aborda que a central sindical tinha uma proposta que se "opunha à visão reducionista, utilitarista da formação e educação", onde estivesse presente a perspectiva da qualidade calcada numa educação "unitária, de caráter científico, tecnológico e politécnico, tendo o trabalho como 
princípio educativo, organizador de sua estrutura, currículos e métodos" (2000, p. 141).

[1] Professor da Faculdade de Educação da UFF, pesquisador do CNPq, pesquisador em estágio de pós-doutoramento no Departamento de Ciência Política da UNICAMP.jrodrig@vm.uff.br. 